\title{
Şiir Çevirisi Eleştirisinde Çevrilebilirlik/Çevrilemezlik İkiliğini Aşmak
}

\section{Banu TELLIOĞLUU1}

\begin{abstract}
$\ddot{\mathbf{O} z}$
Şiirin çevrilemezliği meselesi edebiyat, dilbilim ve çeviribilim alanlarında en çok tartışılan meselelerden biri olmuştur. Şiirin çevrilemez olduğunu iddia edenlerin sayısı bugün bile azımsanamayacak kadar fazladır. Şiirin çevrilemez olduğunu savunanlar şiir çevirisinin olanaksızlı̆ııı erek ve kaynak dillerin, kültürlerin, ve edebiyat geleneklerinin birbirinden farklı olmasına dayandırırlar. Öyleyse, dünyadaki dil, kültür ve edebiyat dizgelerinin birbirinden farklı olması nedeniyle gerekli ve kaçınılmaz olan çeviri, çevrilemezlik iddiası çerçevesinde tam da bu farklılıktan ötürü başarıya ulaşması olanaksız bir etkinlik olarak sunulmaktadır. Kaynak metindeki özün, anlamın ya da kaynak metnin yarattığı edebi etkinin erek dizgeye asla tam olarak aktarılamayacağı yolundaki bu görüş iki metin arasında tam bir örtüşme sağlanabileceği düşüncesiyle, yani çevrilebilirlik iddiasıyla da yakından ilişkilidir; esasen bunlar çevrilebilirlik/çevrilemezlik ikiliğinin iki ayrı kutbuna işaret eden iddialardır. Bu çalışmanın temel amacı, çevrilebilirlik/çevrilemezlik ikiliğinin çeviri eleştirisinde ne türden yöntemsel sorunlar doğurabileceğini tartışmak ve bu ikilikten nasıl kaçınabileceğimizi kültür paradigması içinde önemli yer tutan Skopos Kuramı ışı̆̆ında değerlendirmektir. Bu doğrultuda, öncelikle, araştırmacıların ve eleştirmenlerin dilbilim paradigmasının temel kabulü olan çevrilebilirlik kutbundan çevrilemezlik kutbuna nasıl savruldukları ve Yapısökümcü yaklaşım bağlamında çevrilebilirlik/çevrilemezlik ikiliğinin nasıl yapısöküme uğratıldığı irdelenecek; daha sonra, sözü edilen ikici yaklaşım genel olarak kültür paradigması ama özellikle de Skopos Kuramı ışı̆̆ında değerlendirilecektir. Çalışmanın uygulama bölümünde, Walt Whitman'ın “O Captain! My Captain!” başlıklı şiiri ile bu şiirin Can Yücel tarafından yapılan çevirisi Skopos Kuramının çeviri eleştirisine ilişkin yöntem önerileri çerçevesinde incelenecek, böylelikle Skopos Kuramını temel alan bir şiir çevirisi eleştirisinde çevrilebilirlik/çevrilemezlik ikiliğinden nasıl kaçınılabileceği gösterilmeye çalışllacaktır.
\end{abstract}

Anahtar kelimeler: Şiir çevirisi eleştirisi, çevrilebilirlik, çevrilemezlik, Skopos kuramı, yapısöküm.

\section{Overcoming The Dichotomy of Translatability and Untranslatability in Poetry Translation Criticism}

\begin{abstract}
Untranslatability of poetry has long been a topic of debate within the fields of literature, linguistics and translation studies. Even today the number of those who assert that poetry is untranslatable is considerably high. For these people, poetry is untranslatable because of the profound differences between the target and source languages, cultures, and literary traditions. This view ironically presents the very differences that make translation necessary as the reason behind why translation is predestined to failure. The claim of untranslatability, that is, the claim that it is impossible to transfer the essence, the meaning or the artistic effect of the source text to the target system, on the other hand, is very closely linked to the claim of translatability, which suggests that it is possible to establish an equivalence between the source and the target texts. These views indeed represent the
\end{abstract}

Dr. Öğr. Üyesi, Kırklareli Üniversitesi, Fen Edebiyat Fakültesi, Mütercim-Tercümanlık Bölümü, banutelli@gmail.com [Makale kayıt tarihi: 4.4.2018-kabul tarihi: 14.4.2018]; DOI: 10.29000/rumelide.417493

Adress

Kurklareli University, Faculty of Arts and Sciences, Department of Turkish Language and Literature, Kayalı Campus-Kırklareli/TURKEY e-mail: editor@rumelide.com 
two different poles of the dichotomy of translatability and untranslatability. This article aims to highlight the specific methodological problems this dichotomy poses for the field of translation criticism and seeks to explore what Skopos Theory, which holds a prominent position in the cultural paradigm, might offer to overcome the dichotomy of translatability and untranslatability. To achieve this aim, the article first addresses the question of how researchers and critics who start off with the idea of translatability, the fundamental proposition of the linguistic paradigm, make a sudden swerve to untranslatability. After examining how Jacques Derrida deconstructs the dichotomy of translatability and untranslatability, the article reviews the dualist approach to translation under the light of Skopos Theory. In an attempt to demonstrate how translation critics can actually avoid the dichotomy of translatability and untranslatability, the article finally analyzes Can Yücel's translation of Walt Whitman's renowned poem “O Captain! My Captain!” using the basic guidelines of the model of translation criticism proposed by Hans J. Vermeer and Margaret Ammann.

Key words: Poetry translation criticism, translatability, untranslatability, Skopos Theory, deconstruction.

\section{Giriş}

Şiirin çevrilemezliği meselesi edebiyat, dilbilim ve çeviribilim alanlarında en çok tartışlan meselelerden biridir. Şiir çevirisinin olanaksız olduğunu savunanlar bu olanaksızlığı farklı nedenlere bağlarlar. Örneğin, bazıları, özgün şiirdeki sesin erek dile gerektiği gibi aktarılamayacağını, dolayısıyla da şiir çevirisinin olanaksız olduğunu savunur. Bu düşünceye göre, şiiri şiir yapan şey sestir; şairin seçtiği sözcüklerin belli bir düzende yan yana gelmesiyle oluşan ses o şiire özgü ve biriciktir. Şiir başka bir dile çevrildiğinde bu sözcüklerin yerini başka bir dildeki başka sözcükler alacak, dolayısıyla şiirin o özgün, o biricik sesi, tınısı yitip gidecektir. İoanna Kuçuradi Türk Dili Dergisi Çeviri Sorunları Özel Sayısı için kaleme aldığı "Şiir Çevirisini Değerlendirme ve Türkçede Homeros" (1978) adlı makalesinde bu yaklaşımı şöyle özetliyor:

Şiir çevirisinde başka bir dile aktarılması söz konusu olan işte bu 'ses’tir. Bu aktarım, başka bir dille 'aynı ses’i yaratmakla, başka bir dilin sözcükleri ve olanaklarıyla aynı imgeyi kurmakla olur. Burada, belirli bir dille kurulmuş imgeyi başka bir dille yeniden kurmak, o başka bir dille belirli bir imge arasında bir ilişki kurmak demektir; bu da yepyeni bir iştir. Şiir çevirmeyi en zor yapan, bazen de 'şiir çevrilemez’ dedirten şey işte bu yeni ilişkiyi kurma gerekliliğidir. (s. 113)

Şiirdeki sesin biricikliği üzerine aynı derginin aynı sayısında görüş bildirenlerden biri de İlhan Berk’tir. Berk "Çeviride Şiir Dili” (1978) başlıklı yazısında şiiri çevrilemez kılanın, onun kendine özgü sesi olduğunu açıkça belirtir ve bu sesin aslında 'şairin sesi’ olduğu ima eder:

Gerçekten anlam bir şiiri çevirmeye yetmez. Nedeni de anlam her şey değildir. ... Bir şiiri çevirirken asıl güçlük, şiirin anlatış biçiminde, deyişinde yatar, oradan kaynaklanır. [...] Cummings’in de Ahmet Haşim'in de şür açıklanmaz, bir başka dile çevrilmez dediği şey de budur işte. Bu deyiş, söyleyiş biçimi niçin çevrilmez? Yaratıcısına özgüdür de ondan. Bir yaratı biçimi olduğu için öykünülemez. Çevirmense bir yaratıcı değildir. Ayrıca şiir ondan bunu da istemez. Tektir o. Bir başka türlü de var olamaz. [...] Peki nedir bu çevrilemez dediğimiz yapı? Ozanın bütün yaşamından getirip koyduğu ben sorunu elbet. Assl çevrilemeyen bu 'ben'dir işte. (s. 72) 
Yukarıdaki alıntıda Berk’in "şiirin anlatış biçimi”, "şiirin deyişi” ve "ben” diye betimlemeye çalıştığı özellik Ayfer Altay’ın "Şiir Çevirisinde Çevrilemeyenler” (2001) başlıklı makalesinde ayrıntılandırılır. Altay’a göre şiiri çevrilemez kılan onun dilsel özellikleridir. Şiir çevirisini olanaksız kılan dilsel özellikleri sapmalar, yinelemeler, cinas, özel ad kullanımı, kısa ve eksiltili anlatım ve ritim ve ölçü olarak altı ana başlıkta toplayan Altay bu söz sanatlarının şiir çevirisinde mutlaka kayıplara yol açacağını, dolayısıyla da şiir çevirisini olanaksızlaştırdığını savunur. Altay’ın ifadesiyle “[d]üzyazının çevirilebilirliği artık çeviribilimciler tarafından tartışılmamakta, çevirilebilir olduğu kabul edilmektedir. Ancak șiirin çevirilip çevirilemeyeceği hala tartışma konusudur. Yukarıda gruplar halinde sıralanan öğeler șiiri çevirilemez kılmaktadır" (s. 42).

Asalet Erten’in 1993 yılında kaleme aldığı ve genel olarak edebiyat yapıtlarının çevirisinde karşılaşılan sorunları irdelediği “Çeviri Ediminde Kayıplar Sorunu” (1993) başlıklı makalesi de edebiyat yapıtlarının çevrilemezliğini kayılar üzerinden değerlendirir ve çevrilemezliğin en önemli göstergesi olarak sunulagelen "kayıp" kavramını daha çok yapıtın dilsel özellikleriyle ve biçemiyle ilişkilendirir. Erten’e göre, "yapıtı aktarılan yazarların dil özellikleri, ritimleri ve biçemleri bozulmadan en doğru biçimde aktarılmal, böylece kaynak metindeki etkinin es,değeri erek metinde de verilebilmelidir. Çeviri ediminde karşılaşılan kayıplar bu şekilde en aza indirgenebilir” (s. 328).

Şiirin çevrilemez olduğu görüşünü savunanlardan bazıları da şiirde anlamı oluşturan öğeler üzerinde durur; şiiri oluşturan imge ve sözcüklerin kültür bağımlı olduğunu, her şiirin ancak kendi kültürü içinde bir anlam taşıyabileceğini iddia eder. Şiir bir dilden başka bir dile aktarıldığında, yalnızca belli bir kültür içinde işlev görmek üzere üretilmiş olan bu karmaşık yapı başka bir kültür dizgesinde kendisine yer bulmaya çalışacaktır. Ancak şiirin çevrilemezliğini savunanlara göre bu pek de mümkün değildir. Oktay Rifat “Şiir Çevrilir mi?” (aktaran Alova, 2007) başlıklı yazısında şiirin kültür bağımlı olduğuna dikkat çeker ve şiirde çok anlamlılı̆̆ın çeviriyi olanaksız kıldığını belirtir:

\begin{abstract}
Nerval'in çok ünlü bir sonesinin ilk dörtlüğünü gelişigüzel aktarayım size. 'Kasvetliyim / dulum / avutulmadım. / Kulesi yıkılmış Akitanya prensiyim. / Tek yıldızım öldü, yıldız serpili lavtam / Melankolyanın kara güneşini taşıyor.' Bu dörtlüğün içinde bir iki sözcük var ki Türkçe karşllığı yok. Dizenin başında ilk sözcük olarak kasvetliyim deniyor. Nerval koyu karanlıktan üretilmiş bir sıfatı, karanlıksal gibi bir sözcüğü isim olarak kullanıyor. Anlaşılmaz, güç anlaşılır anlamına da geliyor bu sözcük. Üstelik bir Hıristiyan için karanlıkla şeytan arasında bir ilinti bulunduğunu, bunların şeytana karanlıklar meleği dediğini de anımsatmak isterim. Başka çağrışımları da var. Ne yapacaksınız, nasıl aktaracaksınız metindeki ténébreux sözcüğünün anlamını! Akitanya Fransa’nın tarihsel bir bölgesi. Ortaçağı anımsatıyor Fransıza. Bize bir şey söylemiyor. Kulesi yıkılmış Akitanya prensinin mutsuzluğunu biz nasıl kavrayalım! Not mu düşeceğiz şiirin altına! (s. 45-46)
\end{abstract}

Öyleyse, Rifat'a göre, şiir hangi toplum için yazılmışsa o toplumdaki bireyler için anlam taşır, çünkü onlar yalnızca bir dili değil aynı zamanda, bir dini, bir tarihi ve belli kültürel değerleri paylaşırlar. İşte bu nedenle şiir, bütün diğer edebi türler gibi, kültür bağımlıdır. Şiir çevirisinin ister dilsel, biçimsel, biçemsel açıdan, isterse kültürel göndermeler açısından olanaksız olduğunu vurgulamış olsunlar, yukarıda sunulan bütün bu görüşleri tek bir başlık altında toplamak mümkündür: Şiirde biçim/biçem/anlam birimlerinin birbirinden ayrılamayacağı ve dilin kültürden ayrı tutulamayacağı düşüncelerinden hareketle, yukarıda sunulan görüşlerde çevirinin olanaksızlığı aslında erek ve kaynak dillerin, kültürlerin, ve edebiyat geleneklerinin birbirinden farklı olmasına dayandırılmıştır diyebiliriz. ${ }^{2}$

Rosemary Arrojo (1996) şiir çevirisinin olanaksızlı̆̆ını savunanların bu eğilimlerini “ 'edebi’ gösterenlerin fetişleştirilmesine" bağliyor. Edebiyat metinlerinde, özellikle de şiirde bulunduğu varsayllan ve asla değiştirilmemesi 
Bir başka deyişle, tam da bunlar arasındaki farklılıklardan ötürü gerekli olduğunu düşündüğümüz çeviri, gene aynı nedenle başarıya ulaşması olanaksız bir etkinlik olarak sunulmaktadır. Kaynak metindeki özün, anlamın ya da kaynak metnin yarattığı edebi etkinin erek dizgeye asla tam olarak aktarılamayacağı yolundaki bu görüş iki metin arasında tam bir örtüşme sağlanabileceği düşüncesiyle, yani çevrilebilirlik iddiasıyla da yakından ilişkilidir; esasen bunlar çevrilebilirlik/çevrilemezlik ikiliğinin iki ayrı kutbuna işaret eden iddialardır. Bu çalışmanın temel amacı, çevrilebilirlik/çevrilemezlik ikiliğinin çeviri eleştirisinde ne türden yöntemsel sorunlar doğurabileceğini tartışmak ve bu ikilikten nasıl kaçınabileceğimizi kültür paradigması içinde önemli yer tutan Skopos Kuramı ışığında değerlendirmektir. $\mathrm{Bu}$ doğrultuda, öncelikle, araştırmacıların ve eleştirmenlerin dilbilim paradigmasının temel kabulü olan çevrilebilirlik kutbundan çevrilemezlik kutbuna nasıl savruldukları ve Yapısökümcü yaklaşım bağlamında çevrilebilirlik/çevrilemezlik ikiliğinin nasıl yapısöküme uğratıldığı irdelenecek; daha sonra, sözü edilen ikici yaklaşım genel olarak kültür paradigması ama özellikle de Skopos Kuramı ışığında değerlendirilecektir. Çalışmanın uygulama bölümünde, Walt Whitman'ın "O Captain! My Captain!” başlıklı şiiri ile bu şiirin Can Yücel tarafından yapılan çevirisi Skopos Kuramının çeviri eleştirisine ilişkin yöntem önerileri çerçevesinde incelenecek, böylelikle Skopos Kuramını temel alan bir şiir çevirisi eleştirisinde çevrilebilirlik/çevrilemezlik ikiliğinden nasıl kaçınılabileceği gösterilmeye çalışılacaktır.

\section{Yapısalcı Dilbilimde Çevrilebilirlik/Çevrilemezlik Sorunu ve İkilikleri Aşmak}

Çeviribilimin özerk bir bilim dalı olarak kabul görmeye başlamasından önce çeviri ediminin ağırlıklı olarak edebiyat ve dilbilim alanları içinde ele alındığını biliyoruz. Dilbilim paradigması diye anılan paradigma içinde faaliyet gösteren dilbilimciler 20. yüzyılın ikinci yarısından sonra çeviriye ilişkin görüşlerini daha sistemli biçimde ve bilimsel yöntemler çerçevesinde dile getirmeyi amaçladılar, bu doğrultuda dilbilimin temel kavramlarını kullandılar. Anlayışlarını çevrilebilirlik düşüncesi üzerine temellendiren dilbilimciler yapısalcı bir bakış açısıyla, "mutlak ve nesnel çevirinin yöntemlerini bulma" çabası içindeydiler (Akcan, 2009, s. 21). Paradigmanın öne çlkan isimlerinden J.C. Catford (1965), F. Güttinger (1963), Eugene Nida (1964), Anton Popoviç (1970), Otto Kade (1968) ve Werner Koller (1979) gibi dilbilimciler çeviri olgusunu eşdeğerlik kavramı üzerinden ele aldılar. Ancak bu eşdeğerlik anlayışı daha çok kaynak odaklı ve özcü bir anlayış olarak karşımıza çıkıyordu. Bir başka deyişle, dilbilimciler çeviri edimini kaynak metindeki göstergelerin erek dildeki başka göstergelerle yer değiştirmesi olarak düşünüyor, kaynak metinde var olan ve evrensel olarak kavranabilecek özün uygun stratejilerle başka bir dilde de ifade edilebileceğine inanıyor, dolayısıyla da çevirmenin kaynak metindeki değişmez anlamı ya da özü erek metinde korumaya çalışması gerektiğini vurguluyorlardı (karş. Berk, 2005; Göktürk, 2008; Bengi Öner, 1993; Tellioğlu 2015). Kısacası çevirmenin görevi, kaynak metindeki değişmez, sabit anlamı eksiksiz biçimde saptayarak bir başka dildeki gösterenler ile yeniden ifade etmekti. Bu geleneksel anlayış temelde, çevirinin özgün yapıta kıyasla ikincil bir konuma indirgenmesiyle yakından ilgiliydi. Özgün yapıt yazarın niyetinin tam bir yansıması, çeviri ise her zaman özgün metinden farklılaşan, dolayısıyla özgüne kıyasla çok daha az değer taşıyan bir metin olarak kabul ediliyor ve bu geleneksel yaklaşım doğrultusunda “özgün yapıt idealize edilip yaratıcılıkla ilişkilendirilirken çeviri sınır, eksiklik

gerektiği düşünülen bu edebi özelliklere adeta tapınan yazar ve edebiyatçıların yaklaşımlarını Freud'un fetişe ilişkin yorumları ışı̆̆ında değerlendiriyor (s.212). 
gibi kavramlarla bağdaştırılıyor, tümüyle insana özgü ve nihayetinde kusurlu bir edim olarak değerlendiriliyordu" (Arrojo, 1995, s. 21)3.4

$\mathrm{Bu}$ anlayış doğrultusunda yapılan çeviri incelemelerinde ya da çeviri eleştirilerinde ise kaynak metindeki belli öğe ya da birimler ile bunların çevirmen tarafından öngörülen karşılıkları ikili karşıtlıklar biçiminde ele alınıyor, bilimsel olduğu iddia edilen bu dilsel karşılaştırmadan yola çıkılarak bir çevirinin kaynak metnin eşdeğeri olup olmadığı yolunda kesin sonuçlara varılıyordu. Yaklaşımın çeviri eleştirisi açısından sakıncaları bununla da bitmiyordu. Dilbilimcilerin bu yaklaşımlarının izinden giderek kültür, ideoloji, erek dizge şartları, çevirmenin ve erek okurun algısı gibi meseleleri inceleme alanlarının dışında tutan ve yalnızca dile odaklanan araştırmacılar çeviride daha çok kayıplar üzerinde duruyor, kayıpları açıklamak içinse bazı durumlarda eşdeğerliğin ve dolayısıyla çevirinin mümkün olmayabileceğinden söz etmeye başlıyorlardı. Dönemin önemli dilbilimcilerinden George Mounin (aktaran Arrojo, 1998) dilbilimin bu açmazını şöyle dile getiriyordu:

Çevirmenlerin etkinlikleri çağdaş dilbilim için kuramsal bir sorun oluşturuyor: Sözcüksel, biçimsel ve sözdizimsel yapılarla ilgili genel geçer tezi kabul edersek, çevirinin olanaksız olduğunu da kabul etmek zorunda kalacağız. Fakat çevirmenler var ve çeviri yapmaya devam ediyorlar; biz de onların ürettikleri metinleri kullanıyoruz. Bu durumda neredeyse şunu söylemek mümkün: Çevirinin varlı̆̆ çağdaş dilbilim için tam bir skandal. (s. 31)

Görüldüğü gibi, eşdeğerliğin son derece kısıtlı bir anlamda ele alınması ve kavramın tanımlarında çeviriye ilişkin çok önemli gerçeklerin göz ardı edilmesi yapısalcı dilbilim kuramcılarını ve onların takipçilerini eksiksiz bir çevirinin olanaklı olduğu kabulünden çevirinin olanaksız olduğu kabulüne sürüklüyordu. Çevirinin olanaksız olduğu kabulünden hareket edildiğinde ise çeviri eleştirisi, yalnızca hataların, kayıpların kategorize edilerek listelendiği bir inceleme yazısı olmaktan ileri gidemeyecekti. Bir başka deyişle, çevirinin zaten eksiksiz biçimde yapılamayacağına inanan çeviri eleştirmeninin işi, çevirideki eksikleri saptamak ve bunları çevirinin olanaksızlığına işaret eden birer kanıt olarak sunmaktı. Bu kısır döngü, çeviri eleştirisini de faydasız, hatta anlamsız kılıyor; çevirinin kuramsal ve uygulamalı alanlarına katkı sağlamak şöyle dursun, çeviri uygulamacılarının cesaretlerini kırıyor, kuramsal alanda düşünenlerin ise çeviri edimini geniş bir perspektifle değerlendirmelerine, kültürel ve toplumsal etmenlerle ilişkilendirmelerine engel oluyordu.

Yaklaşımlarını çevrilebilirlik ilkesi üzerine temellendiren geleneksel felsefenin ve yapısalcı dilbilimin temellerini sarsan en önemli kuramlardan biri Yapısökümcü yaklaşım oldu. Babil Kulesi söyleninden yola çıkarak geleneksel felsefeyi ve yapısalcı düşünceyi yapısöküme uğratmayı amaçlayan kuramcı Jacques Derrida kuramının merkezine çeviriyi yerleştirmişti. Samilerin 'adlarını duyurmak' için bir kule inşa etme, tek bir dil oluşturarak adlarını duyurma ve böylece üstünlük kazanma çabalarını anlatan Babil Kulesi söyleni Derrida’ya göre Samilerin "kapalı bir gönderim dizgesine” ulaşma çabalarına işaret ediyordu (Davis, 2007, s. 10). Söylende, Samiler kuleyi tamamlayıp adlarını duyurmaya çalışırken Tanrı'nın duruma müdahale etmesiyle Sami dilinde (ve Tanrı'nın kendi adı bağlamında) bir karışıklık ortaya çlkıyordu. Bir başka deyişle Samiler, dilsel bir aşkınlığa erişmek istemiş ama bunu yaparken

\footnotetext{
3 Kuşkusuz özcülük yalnızca yapısalcı dilbilime atfedilecek bir anlayış değildir. Dilbilim paradigması içinde değerlendirilebilecek, ancak çalışmalarına kültür ve ideoloji gibi kavramları entegre etmiş araştırmacılar olduğu gibi, kültür paradigmasının izinden giden ancak gene de çalışmalarında özcü olmaktan kaçınamayan araştırmacılar da vardır. Buna ilişkin daha kapsamlı bir tartışma için bkz. Arrojo, 1995, s. 25-47.

$4 \quad$ Aksi belirtilmedikçe tüm çeviriler bana aittir.
} 
dillerine karışıklık sokmuşlardı. Peggy Kamuf (aktaran Davis, 2007) bu karışıklığın nasıl ortaya çıktığını şöyle açıklıyor:

\begin{abstract}
Ama aynı zamanda Tanrı kendi adını Sami oğullarına verir. Yani Tanrı’nın özel adı özel olmaktan çıkar. Samilerin dilleri bölünmüş, farklı diller oluşmuştur, fakat Tanrı’nın adı da farklı dillere dağılır, farklı biçimlerde söylenir. Tanrı ancak kendi adının birliğini bozmak, kendi yapısını sökmek suretiyle üstünlüğünü gösterebilmiştir. İnsanlar bütün öteki adlardan önce kendi adını duysunlar diye onların kulaklarına adını söyler. Ancak, bunu başarmak için kendi dışına çıkmak, kendi adının, bir tür adıyla karışabileceği, kendi adının ötekinin dilinde genellenebileceği ve kendinden farklılaşabileceği riskini göze almak zorundadır. Dolayısıyla Tanrı’nın yapısökümü dilin kökenindeki ayrım hareketine işaret eder. Bu hareket içinde, özel olanın birliği, kendini mutlak özel olarak dayatmak istemiş ama bunu başaramamıştır. (s. 12)
\end{abstract}

Öyleyse, evrensel dilin var olabileceği düşüncesini yapısöküme uğratan, bize dilin sınırlarını gösteren Babil Kulesi hikâyesi, Derrida'ya göre, dilin arı bir kökeni, kendisi dışında aşkın bir gönderme noktası olmadığını anlatıyordu. Özel ad dilin, "bir yandan kusursuz çeviriyi olanaksız kılan, öte yandan da çeviriyi yalnızca olanaklı değil aynı zamanda gerekli hale getiren özelliğini” açıkça ortaya koyuyordu (Davis, 2007, s. 16). Bu özellik, yani dilin ayrım hareketiyle anlam üretmesi, çeviri edimini çevrilebilir/çevrilemez ikiliği üzerinden değerlendirmemizi anlamsız kılıyordu; çeviri aynı anda hem olanaksız hem de kaçınılmaz ve gerekliydi. Anlam dilden önce ve dilin ötesinde var olamayacağına göre, kayba uğramadan, yani ‘özel’liğini yitirmeden bir dil dizgesinden bir başka dil dizgesine aktarılamazdı. Kısacası tam bir çevrilebilirlikten (kusursuz çeviriden) söz etmek mümkün değildi. Fakat ayrımlar dizgesi (dil) içinde anlamın oluşması ancak ayrım hareketiyle mümkün oluyorsa, o zaman çeviri de kaçınılmazdı. Dillerin birbirinden farklılaşmasından doğan çeviri sayesinde diller yaşamlarını sürdürecek, ancak çeviri tümüyle sabit, tek, değişmez bir anlama, bir öze varmamızı olanaksız kılacaktı (Davis, 2007). Evrensel dil ülküsünü temel alan geleneksel Batı düşüncesini ve Yapısalcıllğı bu yaklaşımıyla bozguna uğratan, tam bir çevrilemezliği savunmak yerine, çevrilebilirlik/çevrilemezlik ikiliğinin ne denli "sınırlayıcı" olabileceğine dikkat çeken Yapısökümcü yaklaşım, çağdaş çeviri kuramlarında da yavaş ancak son derece anlamlı bir dönüşüme yol açacaktı (Hermans, 2009, s. 300).

\title{
II. Skopos Kuramında Yapısalcılık Sonrası Düşüncenin İzleri
}

Dilbilim paradigmasında değişmez kabul edilen özün ya da anlamın erek dile aynen aktarılması biçiminde sunulan ve dilsel ikili karşıtlıklar üzerinden değerlendirilen eşdeğerlik kavramı, Kültür Paradigması çerçevesinde ele alınabilecek kapsayıcı kuramlarda, yani Çoğul Dizge Kuramı, Erek-Odaklı Kuram ve Skopos Kuramında yalnızca dilsel bir kavram olmaktan çıkmış, kültürel, işlevsel ve ilişkisel bir kavram halini almıştır. Bu da, eşdeğerliğin kültürel ve tarihsel koşullara, çeviri metnin erek kültürde üstleneceği işleve, çeviri metnin erek dizge içinde yer alan başka metinlerle kurduğu ilişkilere göre şekillenen bir kavram olduğu kabulüne işaret eder. Dolayısıyla araştırmacının ya da çeviri eleştirmeninin yapması gereken, erek ve kaynak metinler arasında eşdeğerliğin bulunup bulunmadığını saptamaya çalışmak değil, betimleyici çalışmalar yürüterek çevirinin hangi kültürel ve tarihsel koşullar altında yapıldığı, çeviri metnin yer aldığı dizgenin koşulları, bu koşulların çevirmen kararları üzerinde ne derece etkili olduğu, çeviri eyleminin amacı ve çevirinin hedef kitlesi gibi etmenleri ortaya koymak ve elde edilen sonuçlar doğrultusunda iki metin arasında mutlaka bulunduğu varsayılan eşdeğerliğin türünü ya da derecesini belirlemeye çalışmaktır. Bir başka deyiş̧le, sözü geçen kuramların öncülleri, dilsel ikili karşıtlıklar üzerinden yapılan çalışma sonucunda erek ve kaynak metinler arasında herhangi bir eşdeğerlik bulunmadığına, çeviri olduğu iddia edilen bir metnin kaynak metnin çevirisi 
sayılamayacağına ya da kaynak metnin dilsel ya da kültürel özelliklerinden ötürü zaten çevrilemez olduğuna hükmetmeyi de olanaksız kılar (Karş. Even-Zohar, 1985; Toury, 1985; Toury, 2004; Bengi Öner, 1993; Vermeer 1996; Tellioğlu 2015).

$\mathrm{Bu}$ çalışmada kültür kuramları arasında tek bir kurama, Skopos Kuramına odaklanmamızın birkaç nedeni var: Öncelikle, Skopos Kuramı genel ve kapsayıcı bir kuram olması nedeniyle, çok daha yakın tarihlerde üretilmiş ve ilk bakışta daha çağdaş diye nitelendirilebilecek kuramsal çalışmalara ye $\breve{g}$ tutulmuştur. 1990'lardan itibaren yapısalcılık sonrası düşüncenin izinden giderek çeviribilimde yapısalcı dilbilimsel yaklaşımları, özellikle de ikiciliği ve özcülüğü eleştiren pek çok kuramsal çalışma yapılmış olmasına karşın, bunlar çeviri edimini bütün yönleriyle ele almayı amaçlayan genel ve kapsayıcı birer çeviri kuramı olma iddiası taşımaz. Oysa Skopos Kuramı çeviriye ilişkin pek çok olgu, olay ve etmen arasındaki karmaşık ilişkileri bütüncül bir anlayışla ele alması, çeviri edimini mümkün olan ve bilinen bütün yanlarıyla değerlendirmesi; bunun da ötesinde, bilinen meselelerin ardına uzanıp çevirinin henüz ortaya çımmamış yanlarına ilişkin varsayımlar geliştirmesi, yani olasılıklar sunması açısından "hayli genel ve hayli kapsayıcı" bir kuram olarak nitelenebilir (Schäffner, 1998/2001, s. 236).5 Bu açıdan değerlendirildiğinde, özellikle 1990'lardan sonra ortaya çıkan çeviribilim kuramlarının ele aldıkları temel meseleleri pekâlâ Skopos Kuramının temel öncülleri çerçevesinde değerlendirmek mümkündür. Çeviride ideoloji ve siyasetin etkileri, toplumsal cinsiyet, sömürgecilik ve coğrafya kaynaklı güç dengesizlikleri gibi konulara odaklanan çağdaş kuramcıların çevirmenin bireyselliği, özgürlüğü, taşıdığı ahlaki sorumluluk ve özgürleştirici rolü üzerine geliştirdikleri düşünceler, temelde, Skopos Kuramında 'çevirmenin amacı', 'uzman çevirmen' 'para-, dia- ve idio-kültür' gibi kavramlarla açılanan 'çevirmenin amaç belirleme özgürlüğü', 'çevirmenin işin nihai sorumluluğunu üstlenen bir eyleyici olması' gibi düşüncelerle uyum içindedir.

Çalışmada Skopos Kuramının temel alınmasının ikinci nedeni, Skopos Kuramının yaratıcısı Hans J. Vermeer’in pek çok kuramcının üzerinde ayrıntılı biçimde durmadığı bir mesele, çeviri eleştirisinde yöntem meselesi üzerinde durmuş olması, yani bir çeviri eleştirisi yöntemi önermiş olmasıdır. Kuramcının Margaret Ammann ile birlikte temellerini atıp uygulamaya koyduğu, daha sonra Katharina Reiss tarafından geliştirilen bu yöntem, kuramın temel öncülleriyle uyumlu olması açısından Skopos Kuramı sınırları içinde değerlendirilebilir. Ancak, bakış açımızı daraltmamak ve bu eleştirel yöntemin yaklaşık 30 yll önce üretilmiş bir yöntem olduğu gerçeğini unutmamak adına bu çalışmada, kuramcılar tarafından sunulan çeviri eleştirisi yöntemi, daha çok, genel bir çerçeve gibi kullanılacaktır.

Öte yandan, çeviride 'işlevselliği’ vurgulamış olmasından ötürü Skopos Kuramı pek çok çalışmada yalnızca edebiyat dışı alanlarda yapılan çevirilerle ilişkilendirilmektedir. Schäffner de (1998/2001) alandaki pek çok uygulamacının Vermeer'in kültürel yaklaşımını edebiyat çevirileri için pek de uygun bulmadığını belirtir. Bunun sebebi, edebiyat yapıtlarına "özel bir statü” atfedilmesidir (Schäffner, 1998/2001, s. 238). Örneğin, Mary Snell-Hornby (aktaran Schäffner, 1998/2001) edebiyat metinlerinin işlevlerinin edebiyat dışı metinlerin işlevlerine kıyasla çok daha karmaşık olduğunu, edebiyat metinlerinde biçemin de önemli bir etmen olarak ele alınması gerektiğini iddia eder. Ona göre, "Skopos Kuramının edebiyat çevirisiyle tümüyle ilgisiz olduğunu söyleyemesek de, bu kuramı edebiyat çevirisi bağlamında uygulamaya koymadan önce bir kaç noktayı açıklığa kavuşturmamız gerekir” (s. 238). SnellHornby'nin bu kuşkucu yaklaşımından yola çıkarak, "edebiyat ürünlerinin de belli bir amaç doğrultusunda gerçekleştirilen birer iletişim eylemi” olduklarını vurgulayan, dolayısıyla işlevsel yaklaşımıyla onları da kapsamayı hedefleyen Skopos Kuramının genelde edebiyat çevirisi, özellikle de

Genel ve kapsayıcı kuramların temel özelliklerine ilişkin daha ayrıntılı bilgi için bkz. Culler, 1997. 
şiir çevirisi eleştirisi bağlamında nasıl uygulamaya koyulabileceğini göstermeye çalışmak hem bu kuramın sınırlı biçimde ele alınmasını engellemek, hem de çeviri eleştirisi uygulamalı alanına yöntemsel bir katkı sunmak açısından önemli olabilir (Vermeer, 1998/2001, s. 63).

Skopos Kuramı her çeviri eyleminin belli bir amaç doğrultusunda yapıldığı ve amacın çevirmen tarafından belirlendiği (belirlenmesi gerektiği) düşüncesinden yola çıkar. Her tek durum için ayrı ayrı değerlendirilmesi gereken, yani duruma bağlı olarak çeşitlilik gösterebilecek amaçlar bağlamında değinilmesi gereken en önemli nokta amacın mutlaka erek kültür koşulları göz önünde bulundurularak belirlenmesi ve çeviri metnin amaca uygun biçimde üretilebilmesi için uygun çeviri stratejilerinin kullanılmasıdır. Kullanılacak çeviri stratejilerinin tümüyle duruma ve çevirmenin amacına bağlı olduğunu vurgulayan Vermeer, çevirmene belli çeviri stratejileri dayatmaktan özellikle kaçınır ve bu anlamda özcü ve kuralcı olma hatasına düşmez. Kuramın temel öncüllerinden çıkarılabilecek bir başka önemli sonuç da, çevirmenin amacını sorgulamaya çalışmanın yararsızlığıdır. Zira bir metni belli bir amaç doğrultusunda çevirmeyi hedeflemiş ve kullandığ çevirmeni yanlış bir amaç belirlemekle suçlamak temelde özcü ve dolayısıyla dayatmacı bir yaklaşım olarak düşünülebilir. Ayrıca bu türden bir yaklaşım, her metne içkin sabit bir anlam bulunduğu, bu sabit anlamın hiç değişikliğe uğramadan erek metne de taşınabileceği (taşınması gerektiği) ve bu anlamın yalnızca belli bir amacı/işlevi (özgün metnin amacını/işlevini) gerektirdiği yanılgısını da destekleyecektir. Amaç kavramını, çevirmenin, gene kendisi tarafından belirlenen amaca uygun biçimde hareket edip etmediği, amaçladığı etkiyi yaratmada başarılı olup olmadığı bağlamında ele alan Vermeer, bu kavramı göreli kılarak hem özcülükten kaçınmış, hem de çeviri ediminin merkezine bütün kültürel birikimi ve uzmanlığıyla çevirmeni yerleştirmiş, böylece kuramın vurgusunu özgün yapıtın yaratıcısından kaldırıp erek metnin üreticisi üzerine yerleştirmiş olur. Vermeer’e göre, çeviri metnin erek kültür içerisinde üstleneceği işlev çevirinin amacıyla yakından ilişkilidir. Öyleyse çevirmenin uzmanlığıyla kastedilen de çevirmenin bilinçli tercihlerini kullanarak ve erek kültürü de dikkate alarak belirlediği amaca hizmet edecek uygun yöntemleri kullanması ve çeviri metnin amaçlanan biçimde işlev görmesini sağlamasıdır. En az ürün kadar özneye, yani çevirmene ve onun kültürüne ve kimliğine de odaklan Skopos Kuramında çevirmen, ahlaki sorumluluklarının bilincinde olan, çeviri işinin nihai sorunluğunu üstlenen, karar verme ve bunları uygulama becerisine sahip bir uzman olarak resmedilir (karş. Vermeer, 1996).

Bu kuram çerçevesinde çeviriyi ve çevirmen kararlarını belirleyen değişkenlerin özellikle vurgulandığını söylemek yanlış olmayacaktır. Bu vurgu çeviri etkinliğini mekanik bir dilsel aktarım gibi değerlendiren yaklaşımlara bir yanıt niteliği de taşır. Hemen her çalışmasında çevirinin göreceli doğasını gözler önüne sermeye çalışan Vermeer çevirmenin öznelliği ve özgün metinde sabit bir anlam arayışının yersizliği düşüncelerini alımlama ve anlamlandırma süreçlerine değinerek destekler. Nörofizyolojik bulgulardan hareketle alımlama basamakları üzerinde durduğu “Mögen Sie Zistrosen?” [“Labdanum Alır Mıydınız?”] (1990) başlıklı çalışmasında dikkat çeken en önemli iddia, her türlü göstergenin onu alımlayan kişinin içinde bulunduğu kültürel, toplumsal koşullara ve zihinsel bagajına bağlı olarak anlam üretmesidir (Vermeer, 1990). Bir başka deyişle, A ancak, onu alımlayan B'nin varlığında ve onun bakış açısından bir anlam ve gerçeklik kazanabilir. Tek başına, bağlamdan ve onu alımlayandan ayrı biçimde ele alınamayacak ve bunlardan bağımsız bir anlam üretemeyecek olan A, alımlama süreci sonunda A(B) biçiminde ifade edilebilir (Vermeer, 2002).

Skopos Kuramı çeviri etkinliği bağlamında farklı kültür katmanlarının hem çevirmen hem de çeviri metnin alıcıları üzerinde etkili olduğunu ('para-, dia- ve idio-kültür') ve erek kültürün çeviri etkinliği üzerindeki belirleyici rolünü vurgulayarak kültür paradigması içindeki öteki genel kuramlarla benzerlik 
gösteriyor olsa da, Vermeer son çalışmalarıyla, özellikle de eşdeğerliğe yaklaşımı açısından Skopos Kuramını öteki kültür kuramlarından ciddi ölçüde farklılaştırmıştır. Kuramcı "Çevirinin Doğası" (2004) başlıklı bildiri metninde kültür kuramcılarının getirdiği en büyük yeniliklerden biri sayılan "işlevsel eşdeğerlik' kavramını eleştirerek çeviride işlevler arasında bir özdeşliğin, bir eşdeğerliğin ya da en azından yakın bir benzerliğin yakalanması gerektiğini ortaya koyan çeviri modelinin yanlış olduğunu ileri sürer. Ona göre bu çeviri modelinin temelinde, bir gösteren yerine bir başka gösteren koyulurken gösterilenin aynı kalabileceği inancı yatmaktadır. Hatırlarsak, özcü dilbilimsel yaklaşımlarda bu inanç, metindeki değişmez özün çeviri aracılı̆̆ıyla bir başka dile aynen aktarılabileceği ve dolayısıyla metinlerin çevrilebilir oldukları düşüncesine şekil veriyordu. Vermeer de, Yapısökücülüğe benzer biçimde, göstergenin kendine has bir varlığı olmadığını, içkin bir anlam taşımadığını, alımlayan kişiden, tarihsellikten ve çevre koşullarından bağımsız biçimde anlam üretemediğini belirterek özcü bir kavram olan eşdeğerliğin ne biçim, ne de işlev düzeyinde aranabileceğini iddia eder; böylece sabit, dural bir anlam arayışının genel olarak çeviribilim, özellikle de çeviri eleştirisi açısından faydasızlığını gözler önüne sermiş olur (Vermeer, çev. Dilek Dizdar, 2004). Bu durumda Vermeer’in eşdeğerliği reddetmesi, hem çevrilebilirliği, yani bir metin içinde var olduğu düşünülen özün bir başka dilde hiçbir değişikliğe uğramadan ifade edilebileceği düşüncesini, hem de çevrilemezliği, yani erek ve kaynak metinler arasındaki farklardan ötürü çevirinin aslında mümkün olmadığı yolundaki düşünceyi reddetmesi anlamına gelir. Özgün metin ile çeviri metin arasındaki kaçınılmaz farkları, kültürel, dizgesel, tarihsel, hatta bireysel farklılıklara dayandıran Skopos Kuramının temel öncülleri çerçevesinde değerlendirildiğinde, bu farklar, çeviri etkinliğinin hem nedeni hem de doğal bir sonucudur.

\section{III. Şiir Çevirisi Eleştirisinde İşlevsel bir Yöntem}

Vermeer'e göre, Skopos Kuramını temel alan bir çeviri eleştirisinde esas, “erek metni kaynak metinden bağımsız bir metin olarak ele almaya gönüllü olmaktır” (Vermeer, 1998/2001, s. 63). Bu anlayışla yapılacak bir eleştirel çalışmada eleştirmen, kaynak ve erek metinleri ayrı ayrı ele alacak ve bunların amaç ve işlevleri ile 'metin-içi tutarlılıklarını' mümkün olduğu ölçüde belirlemeye çalışacaktır. Bu da, eleştirmenin, her iki metnin türünü, hangi hedef kitleye hitap etmek üzere yazılmış olabileceğini, eğer varsa yazarın ve çevirmenin önsözlerini ya da yapıtla ilgili başka türlü açıklamalarını, ayrıca yan metinleri değerlendirerek metinlerin kendi dizgeleri içinde nasıl bir işlev üstlendiklerini belirlemeye çalışması anlamına gelir. Ammann ve Vermeer'in kaynak ve erek metinlerin 'metin-içi tutarlılıklarının' belirlenmesinden kastı ise doğrudan metinler üzerinde yapılacak incelemedir. Kuşkusuz bu inceleme de metinlerin içinde bulundukları dizgede nasıl bir işlev üstlendiklerine ya da hangi amaçla üretilmiş olabileceklerine ilişkin bilgi verecektir. Önsöz bulunmadı̆̆ında ya da yan metinlerin azlığında/yokluğunda eleştirmenin metinlerin işlevlerine ilişkin tespiti metinlerin kendileri üzerinde yapılacak inceleme üzerine temellenecektir. 'Metin-içi tutarlılıkların' belirlenmesi aşamasında, metinlerin dilsel, biçimsel ve biçemsel özellikleri, kültürel göndermeleri incelenecek, kısacası metinlerde kullanılan çerçevelerden yola çıkılarak okurun kafasında nasıl bir sahne oluşabileceğine ilişkin yorumlara yer verilecektir6́. Başlangıçta birbirinden bağımsız olarak ele alınan kaynak ve erek metinler son aşamada temel işlev ve amaçları açısından karşlaştırılacaktır. 'Metinlerarası tutarlılığın belirlenmesi' biçiminde ifade edilen bu aşamaya ilişkin en önemli nokta, kaynak ve erek metinlerdeki anlam birimlerinin ya da metinlerin dilsel, biçimsel, biçemsel özelliklerinin ikili karşıtlıklar biçiminde ele alınmamasıdır. Başlangıçta erek ve kaynak metinleri kendi bütünlükleri içinde ele alan eleştirmenin bu iki metnin ayrı ayrı incelenmesi sırasında kullanacağı birimler kuşkusuz birbirinden farklı olacaktır. Bu durumda, eleştirmeni farklı bulgulara götüren farklı birimlerin birbirleriyle karşlaştırılmaları zaten

\footnotetext{
6 Vermeer çevirinin göreceli doğasını açıklamak için C. Fillmore’un Sahne-Çerçeve anlambiliminden faydalanır. Daha
} ayrıntılı bilgi için bkz. Vermeer, 1990; Tellioğlu, 2015; Fillmore, 1977. 
anlam taşımayacağı için, eleştirmenin son aşamadaki karşılaştırmasını metinlerin temel işlevleri ve amaçları üzerinden yapması beklenir (Ammann, 1990; karş. Tellioğlu, 1998).

Skopos Kuramına göre, çeviride amaç, çevirmenden çevirmene değişiklik gösterebileceğine göre, aynı metnin farklı çevirmenler tarafından farklı amaçlarla çevrilmesi de (örneğin erek kültürün beklentilerine uygun bir çeviri yapılması ya da kaynak metnin özelliklerinin korunarak erek okurda yabancılaştırıcı bir etki yaratılması), çeviri metnin işlevinin, özgün metnin işlevinden farklılaşması da (örneğin kaynak dizgede şiir olarak işlev gören bir metnin erek dizgede bir reklam metni haline dönüştürülmesi) pekâlâ kabul edilebilir birer durum olarak karşımıza çıkar. Çevirmenin öngördüğü işlev, kaynak metnin işlevinden farklılaştığında çeviri eleştirmeninin farklı işlevlere sahip iki metin arasındaki tutarlılı̆̆ ('metinlerarası tutarlılık') sorgulaması anlamlı olmayacağından, eleştirmen, daha önce de belirtildiği gibi, çevirmenin amacı ile bu amaca uygun stratejiler kullanılıp kullanılmadığı ve bu sayede amaca ulaşılıp ulaşılmadığı yolunda bir değerlendirme yapmakla yetinecektir (Schäffner, 1998/2001).

$\mathrm{Bu}$ eleştirel yöntemde çevrilebilirlik/çevrilemezlik ikiliği ustaca saf dışı edilir çünkü eleştirmenden eleştirisini belli bir ideal ya da beklenti üzerine değil, yalnızca hâlihazırda üretilmiş olan bir çeviri metin üzerine temellendirmesi beklenir. Üstelik erek ve kaynak metinlerin birbirinden bağımsız biçimde ele alınması, bunlara ilişkin karşılaştırmanın da yalnızca işlev üzerinden yapılması kaynak metne daha öncelikli ve saygın bir konum atfedilmesini engeller. Erek metin ile kaynak metin arasında işlevsel bir tutarlılık önkoşmayan bu yöntem, ayrıca, çeviri kavramının kapsamını genişleterek kaynak metinden farklı biçimde işlev görmesi hedeflenen bir erek metnin de pekâlâ çeviri olarak değerlendirilebileceğini ortaya koymuş olur. Çevirinin işlevine ve çevirmenin amacına yapılan vurgu ve bunların kaynak metnin işlevinden ve yazarının belirlediği amaçtan farklılaşabileceği düşüncesi, bir anlamda, dilde ve çeviride ayrım hareketinin önemine dikkat çeker. Aslında, ayrımın bu eleştiri yönteminin temelini oluşturduğu iddia edilebilir. Dil nasıl ayrım hareketiyle anlam üretiyorsa çeviri de ayrımlar üzerinden yeni anlamlar üretir. Öyleyse çeviri eleştirmeni, çeviri etkinliğiyle ortaya çıan yeni anlamların izini sürecek, hem kaynak ve erek metinlerin birbirinden nasıl ve niçin farklllaştı̆̆ı üzerine düşünce üretecek hem de bunlar arasındaki kaçınılmaz bağlara dikkat çekecek; böylelikle kaynak ve erek metinlerin o ya da bu biçimde birbirinden farklılaşacağı gerçeğini çeviri ediminin doğasından kaynaklanan bir gerçek olarak değerlendirerek çevrilebilirlik/çevrilemezlik ikiliğinden kaçınmış olacaktır.

Çalışmanın bundan sonraki kısmında yukarıda sözü edilen çeviri eleştirisi yönteminin temelleri Walt Whitman'ın “O Captain! My Captain!” başlıklı şiirinin Can Yücel tarafından yapılan çevirisini incelemek üzere kullanılacaktır. Bu doğrultuda özgün metin ve çeviri metin ayrı ayrı ele alınacak, yani her metnin 'metin içi tutarlılıkları' birbirinden bağımsız olarak değerlendirilecektir. Ancak erek metin üzerinde yapılacak incelemede, çevirmen kararlarının belirgin biçimde ortaya konabilmesi adına, kaynak metinden de faydalanılacaktır. Sonuç bölümünde ise bu iki metin arasında 'metinlerarası tutarlılık' olup olmadığı, metinler üzerinde yapılan incelemeler sonucunda belirginleşen yazar ve çevirmen amaçları ve metinlerin işlevleri üzerinden belirlenmeye çalışılacaktır. 


\section{Walt Whitman'ın “O Captain! My Captain!” başlıklı şiirinde alegorik özellikler, deniz/deniz yolculuğu teması ve söylem}

\section{O Captain! My Captain!}

O Captain! my Captain! our fearful trip is done,

The ship has weathered every rack, the prize we sought is won,

The port is near, the bells I hear, the people all exulting,

While follow eyes the steady keel, the vessel grim and daring;

But O heart! heart! heart!

$\mathrm{O}$ the bleeding drops of red,

Where on the deck my Captain lies, Fallen cold and dead.

O Captain! my Captain! rise up and hear the bells;

Rise up--for you the flag is flung for you the bugle trills,

For you bouquets and ribboned wreaths for you the shores a-crowding,

For you they call, the swaying mass, their eager faces turning;

Here Captain! dear father!

This arm beneath your head!

It is some dream that on the deck,

You've fallen cold and dead.

My Captain does not answer, his lips are pale and still;

My father does not feel my arm, he has no pulse nor will;

The ship is anchored safe and sound, its voyage closed and done;

From fearful trip the victor ship comes in with object won;

Exult $\mathrm{O}$ shores, and ring $\mathrm{O}$ bells!

But I, with mournful tread,

Walk the deck my Captain lies,

Fallen cold and dead.

\section{Walt Whitman}

Walt Whitman'ın ilk kez 1865 yllında Saturday Press'de ve hemen aynı yll Drum-Taps [Trampet Sesleri] adlı şiir kitabının içinde yayımlanan "O Captain! My Captain!” başlıklı şiiri Amerikan şiirinin belki de en bilinen, en popüler örneklerinden biridir. Amerikan İç Savaşıyla ilgili şiirlerden oluşan bu kitabı uzun zamandır yayımlamak isteyen, ancak yayınevleri tarafından reddedilen şair nihayet Nisan 1865'de kitabı kendi olanaklarıyla yayımlamak üzerek harekete geçer. Ancak kitap basım aşamasındayken gerçekleşen talihsiz olay şairi derinden etkiler ve kitabın nihayet basılıyor olmasından duyduğu sevinci gölgeler: Abraham Lincoln bir suikaste kurban gitmiştir. Hemen yayım sürecini durdurarak kitaba Abraham Lincoln'ın anısına bir bölüm eklemeyi uygun bulan şair, "O Captain! My Captain!” başlıklı şiirini de şavaşın bitişini ve Lincoln'ın öldürülmesini konu alan 18 şiirden oluşan bu 24 sayfalık bölüm içine yerleştirir. Kitabın bütününe bakıldığında, şiirlerin coşkudan kedere doğru evrilen bir ruh halini anlattığı söylenebilir. Bu ruh hali şairin savaşla ilgili duygularını özetler niteliktedir. Kitabın başlığı da hem savaş öncesinde çalınan trampetin yarattığı coşkuyu, hem de askeri 
cenaze törenlerinde çalınan trampetin uyandırdığı kederi ifade etmesi açısından önemlidir (LeMaster J.R. and Donald D. Kummings, 1998).

“O Captain! My Captain!”, Whitman şiirleri arasında en sık okunan ve antolojilerde en sık yer verilen yapıt olarak dikkat çeker. Şairin, başka yapıtlarını unutturacak düzeyde ilgi gören bu şiiri yazdığına pişman olduğunu ifade etmiş olması da ilginç bir bilgidir. Gene de, Whitman 1865 yılından sonra şiiri ufak değişikliklerle başka derlemelerin içinde sunmuş ve hemen hemen her konuşmasında bu şiiri okumayı sürdürmüştür (LeMaster J.R. and Donald D. Kummings, 1998). Amerikan tarihinin en sevilen başkanlarından olan Lincoln'a ağıt niteliği taşıyan bu şiir zaman içinde Amerikan milliyetçiliğinin ve Amerikan ulusunun bir sembolü haline gelmiştir (Reynolds, 2005). Şiirde geminin savaşta ölen kaptanının Amerikan İç Savaşı'nda Konfederasyonu zafere götüren Abraham Lincoln'ı, kıyıya yaklaşan geminin ise Konfederasyonu simgelediği düşünülmektedir. Öte yandan, Encyclopedia of American Literature of the Sea \& Great Lakes'e [Amerikan Edebiyatında Deniz ve Büyük Göller Ansiklopedisi] (2000) göre, belirgin deniz imgeleriyle örülü olan şiir Amiral Nelson komutasındaki İngiliz deniz filosunun 21 Ekim 1805 tarihinde Trafalgar açılarında Fransız ve İspanyol filolarına karşı kazandığı zafere gönderme yapıyor olabilir. Şiirde Nelson'a açık bir gönderme bulunmamasına karşın hayatını hiçe sayarak savaşan Nelson'ın zaferin hemen sonrasında hayatını kaybetmesi ile Konfederasyonu zafere taşıyan Lincoln'ın, zaferi kutlayamadan öldürülmesi arasındaki paralellik dikkat çekicidir (Gidmark, 2000).

Şiir pupa yelken, limana doğru yaklaşan bir gemiyi anlatır. Geminin kaptanının ölü bedeni güvertede yatmaktadır. Şiirin anlatıcısı kaptanın ölümü üzerine duyduğu üzüntüyü dile getirirken bir taraftan da belli ki büyük bir hayranlık ve sevgi duyduğu ve ölümüne inanamadığı kaptana hitap eder; ona kıyıda kendisini heyecan içinde bekleyen kalabalı̆̆ gösterir. Geminin uzun ve zorlu bir deniz yolculuğundan döndüğü, yolculuk boyunca çeşitli tehlikelerle karşılaşmasına karşın her zorluktan muzaffer çlktığı, ancak kaptanın zafer sevincini kıyıdakilerle paylaşamadan talihsiz bir şekilde öldüğü bilgisi anlatıcının ağzından son derece ritmik bir dille okuyucuya aktarılır. Kaptanın zamansız ölümü ile gemiyi karşılamak üzere limana akın eden kalabalığın büyük coşkusu arasındaki belirgin karşıtlık okurda ancak trajedilerin yaratacağı türden bir duygu yoğunluğu yaratır.

Walt Whitman neredeyse bütün yapıtlarını "serbest ölçüyle kaleme alan ilk Amerikan şairi" diye anılır (Isham, 2004, s. 280). Ancak Whitman'ın diğer şiirlerinin aksine, bu şiirde ölçü ve kafiyeden faydalanıldığı göze çarpar. Sekiz dizeden oluşan üç kıtalık şïrdeki ölçü ve kafiye düzeni yakından incelendiğinde, şairin tek bir ölçüden faydalanmadığı, şiirdeki ritmi, belki de zaferden duyulan sevinç ile kaptanın ölümünden duyulan acı arasındaki karşıtlığı vurgulayabilmek için, farklı dizelerde farklı ölçüler kullanarak değiştirmeyi tercih ettiği görülür. Örneğin, şiirde ağırlıklı olarak 'iambic meter' adı verilen, bir kısa hecenin ardından bir uzun hecenin vurgulanmasıyla oluşan ölçü kullanılmıştır. Bu ölçüyle oluşan ritim, her kıtada dördüncü dizeden sonra farklılaşır; dizeler de belirgin biçimde kısalır. Kafiye düzeni için de benzer saptamalar yapmak mümkündür. Şiirin bütününde her zaman tam kafiyelerden faydalanılmadığı, tam kafiyelerle yaratılan ritmik etkinin bazı dizelerde yarım kafiyelerle azaltıldığı görülmektedir. Gene de, şiirin biçimsel ve biçemsel özellikleri açısından Whitman şiirleri arasında farklı bir yer tuttuğu açıtır. "Daha geleneksel, belli bir biçemsel düzen" sunan bu şiirin, kafiye ve ölçü düzeniyle klasik edebiyattaki ve Anglosakson edebiyatındaki ağıt geleneğine yaklaştığı da söylenebilir (LeMaster J.R. and Donald D. Kummings, 1998, s. 193).

Whitman'ın şiirlerinde deniz imgesi ve denizcilik söylemi büyük önem taşır. Şair pek çok şiirinde denize, deniz yolculuklarına, denizdeki gel-git olaylarına yer vermiştir. Onun şiirinde deniz yolculuklarına 
çıkanlar genellikle maceracılık, kahramanlık, gerçekçilik ve sağlam karakterlilik gibi özelliklerle donanmıştır. Ancak deniz imgesi hayattaki çeşitli zorluklarla, yaşlanma ve ölüm gibi yaşamın kaçınılmaz yanlarıyla da özdeşleştirilir. Whitman'ın şiirinde sıkça rastlanan deniz imgesi ve deniz yolculukları şairin denizle fazlaca haşır neşir olduğu çocukluk ve gençlik yıllarından kaynaklanıyor olabilir. Ayrıca, şairin doğaya olan yakın ilgisi, denizin de doğanın önemli bir parçası olması deniz temasının Whitman şiirinin belkemiğini oluşturması açısından önem taşıyabilir (Reynolds, 2005). Ancak bu saptamalar spekülatif olmaktan ileri gidemeyecek ve bu çalışma için yeterli veri sağlamayacaktır. Bu eleştirel çalışmada asıl üzerinde durulması gereken "O Captain! My Captain!” adlı şiirin genel olarak dünya edebiyatında, özellikle de Anglosakson edebiyat geleneğinde rastlanan deniz ve deniz yolculuğu temalarından nasıl izler taşıdığıdır.

Antik Yunan Edebiyatından başlayarak dünya ve özellikle de Anglosakson edebiyatına göz attığımızda, deniz ve deniz yolculuğu imgelerinin genellikle sembolik biçimde kullanıldığını görürüz. Örneğin Antik Yunan'ın lirik şairi Alkaeus, şiirlerinden birinde korkunç bir firtınada ilerlemeye çalışan bir gemi imgesini kullanmıştır. Şiirde sembolizm çağrıştıracak herhangi bir işaret olmamasına karşın Heraklitus bu şiiri politik çatışmaları anlatan bir alegori olarak yorumlamıştır. Eğer Heraklitus'un yorumu doğruysa bu şiir geminin devleti, gemi yolculuğunun da politik çatışmaları simgelediği ilk şiirlerden biridir. Gemi-devlet alegorisi bu şiirden sonra çeşitli yapıtlarda, örneğin Sofokles'in Antigone'sinde ve Platon'un Devlet'inde karşımıza çıar. Ayrıca Dante'nin İlahi Komedya'sında da (Cehennem 6.77) Floransa büyük bir firtınada ilerlemeye çalışan ve dümencisi olmayan bir gemiye benzetilir. Anglosakson edebiyatında zorlu deniz yolculuğu temasından faydalanan ve alegoriye başvuran en önemli isimler kuşkusuz Shakespeare (Frrtına) ve Herman Melville'dir (Moby Dick). Politik alegori özelliği taşımadığı hallerde de tehlikeli deniz yolculuğu temasının genel olarak Batı edebiyatı geleneğinin yapı taşlarından biri olduğu iddia edilebilir. Kutsal metinlerde anlatılan Nuh'un Gemisi hikâyesinden başlayarak binlerce edebiyat yapıtında tehlikelerle dolu açık denizler, dar boğazlar, anaforlar, kutsal güçlere karşı savaşan deniz canavarları, ıssız adalar önemli temalar olarak karşımıza çıkar. Homeros'un Odysseia, Virgil’in Aeneid, Coleridge'in Yaş̧ Gemici adlı yapıtları bu temaların işlendiği yapıtlardan yalnızca birkaçıdır (Ferber, 1999).

Walt Whitman’ı “O Captain! My Captain!” adlı şiiri de işte bu sözünü ettiğimiz geleneğin bir parçasıdır. Şiir yalnızca tematik olarak değil, temaya uygun sözcük seçimi açısından da Batı edebiyatı geleneğinden, özellikle de Anglosakson edebiyatı geleneğinden izler taşır. Deniz ve denizci imgelerinin sıkça kullanıldığı İngiliz, İrlanda ve İskoç edebiyatında, özellikle de sözlü edebiyatta, yani halk şarkılarında (baladlarda) rastlanan denizcilikle ilgili sözcükler Whitman'ın bu şiirinde karşımıza çıkar. Örneğin, captain (kaptan), port (liman), ship (gemi), vessel (gemi), keel (gemi/karina/omurga), deck (güverte), shore (kıyl), anchor (demir/demirlemek), voyage (yolculuk), trip (yolculuk) gibi sözcükler denizcilik terminolojisinin birer parçası olarak şiirdeki yerini alır. Ancak bunlar en sıradan Amerikan ya da İngiliz okurunun bile anlayabileceği türdendir. Gemicilik ve denizcilik terminolojisinin ne kadar kapsaml olduğu ve sıradan okurun pek de aşina olmadığı sözcüklerden oluştuğu göz önüne alındığında, bu şiirde kullanılan denizcilikle ilgili terimlerin okurun metni anlamasına engel olmayacak biçimde seçildiği açıktır. Ayrıca, şiirdeki söylemin belirgin yerel özellikler taşımadığı, örneğin Amerika’nın belli bir bölgesinde konuşulan bir ağızdan, denizci argosundan ya da İrlanda yahut İskoç şiirinin dilsel özelliklerinden faydalanılmadığı, şiir dilinin son derece sade olduğu, kısacası şiirin standart İngilizce ile kaleme alındı̆̆ görülmektedir.

Öte yandan, 'O ... !' bir hitap biçimi ya da yakarış yahut yüce olana seslenme bildiren bir ünlem olarak sözlü ve yazılı edebiyatın kahramanlık söylemi içeren hemen hemen bütün örneklerinde, örneğin 
destanlarda, ayrıca sevilen ya da hayranlık duyulan birinin ölümü üzerine kaleme alınan ağıtlarda ve önemli kişiliklerin, özellikle de devlet adamlarının övüldüğü methiyelerde kullanılagelmiştir. Şiirde başlık da dâhil olmak üzere hemen her kıtada karşımıza çıkan bu sesleniş biçimi şiirin bir ağıt olduğu yolundaki yorumu doğrular niteliktedir. Anlatıcı şiirin başında kaptanına 'O Captain,' diye seslenerek onu yüceltir, bu hitapla ona duyduğu saygı ve hayranlığı dile getirmek ister gibidir. Ancak anlatıcının şiirin başlangıcında göze çarpan coşkulu ifadeleri ('the prize we sought is won', 'the bells I hear', 'the people all exulting', 'the vessel grim and daring') beşinci dizede ani bir değişikliğe uğrar. Beşinci dizedeki 'O Heart, heart, heart' nidası anlatıcının kaptanın ölümünü fark ettiğini okuyucuya bildirir. Bu noktadan sonra şiirin başındaki coşku dolu söylem yerini ağır bir ağıt havasına bırakır. 'O Heart, heart, heart' nidasında 'heart' sözcüğünün tekrarı ile okuyucu anlatıcının ne kadar büyük bir düş kırıklığı ve derin bir acı duyduğunu anlar. Bu tekrar okuyucuyu adeta anlatıcı ile birlikte yas tutmaya, ağıt yakmaya davet eder. Şiirin son kıtasında karşımıza çıkan 'Exult, O shores, and ring, O bells!' dizesinde ise anlatıcı kıyıda kendilerini beklemekte olanlara seslenir. Muzaffer gemi kıyıya yaklaşmaktadır, ancak geminin kaptanı ölmüştür. Burada bir emir yapısıyla birlikte karşımıza çıkan sesleniş son derece buruk, acı ve çaresizlik dolu bir zafer narasını andırır. Zafer sevinci ile muzaffer olanın ölümünden duyulan acı arasındaki karşıtlık işte bu son kıtada doruğa ulaşmış, şair bu kısacık şiiriyle okur üzerinde büyük tragedyalarınkini aratmayacak bir etki bırakmayı başarmıştır.

Özetle, şiir tematik açıdan Batı edebiyatının izinden gider, deniz ve deniz yolculuğu imgeleri altına büyük bir devlet adamının trajik hikâyesini gizler, yani daha önce belirttiğimiz gibi Batı edebiyatında sıkça rastlanan bir alegoriye başvurur. Bunun dışında, şiirde ağıta özgü söylem dikkat çekicidir. Bu açıdan bakıldığında da şiirin Batı edebiyatı, özellikle de Anglosakson edebiyat geleneğinde önemli yer tutan ağıt türünün en güzel ve çağdaş örneklerinden biri olduğu söylenebilir. Ayrıca birinci kıtadan sonra söylemin aniden değişmesi, zafer coşkusu ile muzaffer olanın ölümünden duyulan acının birbirine karşıtlık oluşturacak biçimde okuyucuya sunulması bize şiirin tragedya geleneğinden de izler taşıdığını düşündürür. Ancak şiir dilsel özellikleri açısından sadedir. Deniz ve denizcilikle ilgili sözcükler şiirin belkemiğini oluşturur, fakat bunlar sıradan bir insanın da rahatça anlayabileceği türdendir. Kısacası şair bu şiirinde tematik, alegorik ve biçimsel anlamda geleneğin peşinden giderken dilini sade tutarak modernliğini korur.

\section{Can Yücel’in “Oy Reis Koca Reis” başlıklı çevirisinde Türk edebiyatı geleneğinin izini sürmek}

\section{Oy Reis Koca Reis}

Oy reis, koca reis, alnımızın akıyla döndük seferden.

Savuşturup onca belâ, onca firtınayı, sonunda murada erdin.

İşte liman, bak, çanlar çalıyor, bayram ediyor ahali,

Gördüler pupa yelken geliyor, gözü pek, gözü yeşil yelkenli.

Neyleyim, neyleyim ki ama...

$\mathrm{Bu}$ kan damlalarını nideyim?

Gayri uzanmış güverteye reis,

Soğumuş ellerini mi öpeyim? 
Oy reis, koca reis, kalk da şu çanları dinle bari!

Baksana, senin bayrağın çekilen, senin şarkın söyledikleri!

Senin için bu çiçekler, senin için toplaştılar sahillerde,

Seni çağırıyorlar, bak, senin adın geziyor dillerde!

Gel, reis ağacı̆̆ım benim,

Kolumun üstüne yatırayım seni.

Çoktan öldüğünü unuttum ama,

Bu kan damlalarını nideyim?

Reis cevap vermiyor sözüme, dudakları söylemez olmuş,

Ağam kolumu duymuyor bile, ne yüreği ne kalbi kalmış.

Sağ salim demir attı gemi, bitti artık sona erdi sefer,

Savuşturup onca belâyı, kazanılan bir güzelim zafer.

Bayram etsin sahil, çalsın davullar!

Yalnız bırakın beni gideyim!...

Reisin yattığı güvertenin üstünde

Böyle dolaşmayıp da nideyim?

Çeviri: Can Yücel

Can Yücel’in Walt Whitman'dan çevirdiği “Oy Reis Koca Reis” başlıklı şiir ilk kez 1957 yılında yayımlanan Her Boydan: Dünya Şïrinden Örnekler adlı kitapta, dünya edebiyatından seçilmiş farklı şiirlerin çevirileri arasında yer alır. Uzun yıllar yılmadan çeviriyle uğraşmış, dünya şiirinden pek çok örneği Türkçeye kazandırmış ve yaptığı her çeviriyle, deyiş yerindeyse, sansasyon yaratmış olan Can Yücel, bütün çevirilerinde kendi şiirini yazdığı ve kaynak metindeki kültürel göndermeleri yerlileştirdiği için çoğu kez eleştirilmiştir. Can Yücel'in Her Boydan başlığı altında topladı $\breve{g} ı$ şiir çevirileri de erek okura hiç yabancı gelmeyecek söylemleriyle, Can Yücelce söyleyişleriyle dikkat çeker. Üstelik şair, bir söyleşisinde çeviri şiirlerden oluşan Her Boydan başlıklı kitaba kendi şiirlerini de eklemiş olduğunu, ancak bunu kimsenin fark etmediğini belirtmiştir (Karantay, 1989). Kısacası, Her Boydan'ın içinde yer alan Can Yücel çevirileri yalnızca çevirmenin kendine özgü çeviri stratejilerini gözler önüne sermesi açısından önem taşımaz. Bunlar, aynı zamanda, Can Yücel’in çeviri ile özgün yapıt arasında herhangi bir ayrım gözetmeksizin kendi şiirlerini bir çeviri seçkisi içine eklemiş, kendi şiirleriyle dünya şiirinden örnekleri adeta tek bir metinmiş gibi sunmuş olması açısından da önem arz eder. Can Yücel’in özgün metin ile çeviri metin arasında statü açısından herhangi bir fark gözetmediğine yorulabilecek bu yaklaşımının, aynı çeviri şiir derlemesinde yer alan "Oy Reis Koca Reis” başlıklı şiirde kullanılan çeviri stratejilerini anlamlandırmada ve çevirmenin amacını saptamada eleştirmene yardımcı olacağı açıktır.

Her Boydan: Dünya Şïrinden Örnekler başlı̆̆ılla ilk kez 1957 yılında yayımlanan derleme günümüze dek farklı yayınevleri tarafından defalarca yeniden basılmıştır. İlk baskısıyla ilgili hemen hiç bilgiye ulaşamadığımız derlemenin sonraki baskıları arasındaki benzerlikler, yeniden basımlarda kitap üzerinde herhangi bir değişikliğe gidilmediği, ilk basımda derlemede yer alan bütün öğelerin sonraki basımlarda da korunduğu yolundaki tahminimizi güçlendirmektedir. Bu çalışma için kullanılan versiyon, Papirüs Yayınevi tarafından 1993 yılında piyasaya sürülmüştür. Kitap kapağında, başlığın hemen altında Can Yücel'in adı geçmektedir; yani kapakta Can Yücel'den çevirmen olarak söz edilmez. 
Ancak, başlıktaki "dünya şiirinden örnekler” ifadesi ve iç kapaktaki “Türkçesi: Can Yücel” ifadesi okura kitabın dünya şiirinden bir derleme olduğunu ve şiirlerin de Yücel tarafından çevrildiğini anlatır. Derlemeye ilişkin en ilginç noktalardan biri, hiç kuşkusuz, kitaba yazılan giriş yazısıdır. Ünlü edebiyatçı ve çevirmen Sabahattin Eyüboğlu tarafından kaleme alınan "Can Yücel’in Şiir Çevirileri” başlıklı bu yazı gene 1957 yılında Yeni Ufuklar dergisinde yayımlanmıştır. Yazısını "şiir başka bir dile çevrilebilir mi, çevrilemez mi?” sorusuyla açan Eyüboğlu çoğu edebiyatçının şiir çevirisinin olanaksızlığını vurguladığını, ancak her nasılsa şiir çevirilerinin hep yapılageldiğini, Tanrının sözünün bile başka dillere çevrilerek nice edebiyatçıya ilham vermeyi sürdürdüğünü ifade eder (Eyüboğlu, 1993, s. 5). Türk şiirinin gelişmesinde de çeviri yapıtların çok etkili olduğunu belirten Eyüboğlu'na göre Yücel'in bu derlemesi "Türk şiirinin en önemli olaylarından biri[dir]" (Eyüboğlu, 1993, s. 6). Yücel'in derlemedeki şiirleri "kendi şiirini söyler gibi" çevirmesi Eyüboğlu için olumsuz değil, tam tersine olumlu bir gelişmedir (Eyüboğlu, 1993, s. 7). Eyüboğlu, Yücel’in çeviriye ilişkin zorluklarla ustaca başa çıktığını, biçim ile içeriği olgunlukla dengede tutmayı başardığını, okura hem kendi sesini hem de özgün yapıtın şairinin sesini duyurabildiğini söyleyerek Yücel’in çeviri stratejilerini açıkça desteklediğini ortaya koymuş olur.

Derleme içinde, şairlere belli bölümler ayrıldı̆̆ı, yani her şairden çevrilen şiirlerin bir arada verildiği görülür. Walt Whitman'a ayrılan bölümde “Oy Reis Koca Reis” şiirinin yanında üç Whitman şiiri daha yer alır. Fakat asıl ilginç olan, Yücel'in derlemenin sonuna "Şuara" başlı̆̆ıla şairlerle ilgili görüşlerini ifade ettiği bir bölüm eklemiş olmasıdır. Bu bölümde Walt Whitman için yazdıkları, Yücel’in kaynak metni nasıl algıladığını ve çeviri stratejilerini anlamak açısından önemli olabilir. Whitman hakkındaki ifadeler şöyledir:

\begin{abstract}
“Demokrasi”nin bu büyük ozanı, Amerika'da eşitliğin, özgürlüğün, kardeşliğin bütün dünyaya açı bir umut ışığı olarak henüz yaşadığı yllarda, er geç bulunacak bir yaşam tarzının sözcüsü olma yükünü sırtlanarak, umulmadık sadelikte, umulmadık bir halkçllı içinde (ve belki de yeni bir popülizmin yanlış temellerini atmacasına) gürül gürül bir ses, bir biçim yarattı... (Yücel, 1993, s. 177)
\end{abstract}

Çeviri metne baktığımızda, bu metnin gerek kullanılan imgeler, gerek sözcük seçimleri gerekse hitap ve tekrarlar açısından erek edebiyat dizgesinde önemli bir yer tutan ağıt geleneğiyle örtüştüğü söylenebilir. Sözlü gelenek içerisinde değerlendirilen ağıtlar, nesilden nesle aktarılan ve genellikle müzik eşliğinde söylenen şiirlerdir. Dünya edebiyatı örneklerinde olduğu gibi bunlarda da çoğunlukla insanın ölüm karşısında duyduğu acı, keder ve çaresizlik konu edilir. Bilindiği gibi Cumhuriyet sonrası Türk edebiyatında 1920'lerin sonlarından itibaren bir toplumcu gerçekçi anlayış hüküm sürmeye başlamıştır. Bu dönemde "sanat toplum içindir" tezini savunan çoğu Türk edebiyatçısının, bu tezi destekleyen siyasal duruşları da (halkçılık) belirgindir. Buna paralel olarak dil sadeleşmiş, halk söyleyişleri edebiyata girmiş, modern olmakla birlikte tarihini ve geleneğini dışlamayan bir edebiyat anlayışı gelişmiştir. 1940-60 arasında bu eğilimler genellikle Köy Romanı diye nitelenen bir akımın ortaya çıkması biçiminde kendini göstermiş, Köy Enstitülerinden yetişmiş pek çok yazar yapıtlarında köy gerçeklerini işlemeye başlamıştır. Can Yücel'in de bu toplumcu gerçekçi anlayıştan etkilendiğini söylemek yanlış olmayacaktır. Başta Nazım Hikmet olmak üzere Orhan Kemal, Yaşar Kemal, Kemal Tahir gibi önemli edebiyatçlların toplumcu gerçekçi bakış açları Can Yücel'in şiir dili üzerinde mutlaka bir ölçüde etkili olmuştur. Öyleyse Yücel'in çevirisinde karşımıza çıkan halk edebiyatı etkileri de şaşırtıcı olmamalıdır. Sabahattin Eyüboğlu da yazdığı giriş yazısında şairlerin "nice sapıtmalardan sonra nihayet Cumhuriyetle" halk dilinde yazılması gerektiği gerçeğini kavradıklarını, "şiirde sokağın sarayın hakkından gel[diğini]” şiir dilinde başlangıç noktasına, yani Yunus Emre’ye dönüldüğünü ifade ederek Can Yücel'in hangi gelenekten beslendiğini gözler önüne serer (Eyüboğlu, 1993, s. 6). Gene de, bu 
tespitleri desteklemek için çevirmenin dilsel seçimlerini daha ayrıntılı biçimde ele almak yerinde olacaktır.

Erek metinde başlıktan itibaren hemen hemen bütün dizelerde halk diline özgü söyleyişler ve erek okuru kendi kültürüne ve tarihine gönderen deyiş ve sözcükler yer alır. Özgün metinde olduğu gibi çeviri metinde de şiirin başlı̆̆ı ilk ve ikinci kıtaların hemen başında kullanılmıştır. Başlık için Türkçede seçilen sözcük grubu birkaç açıdan değerlendirilebilir. Öncelikle, hitap biçimi olarak kahramanlık ve yüceltme çağrıştıran ‘Ey’ sözcüğünün değil de ‘Oy’ sözcüğünün seçilmiş olması Can Yücel’in şiirdeki ağıt özelliğini erek metinde korumak istediğine işarettir çünkü Türkçede ‘Oy' sözcüğü özellikle halk şiir ve türkülerinde büyük bir acı ve matemin ifadesidir. Türk kültüründe bir ölünün ardından yakılan ağıtlar 'Oy' sözcüğü ile başlar ve sözcüğün defalarca yinelenmesiyle ilerler. Bunun dışında sevilen birinin kaybından ya da sevgiliye ulaşamamaktan duyulan acı pek çok halk türküsünde yine bu biçimde ifade edilir.

Başlıkla ilgili değinilebilecek bir başka nokta da 'reis' sözcügüdür. 're's' kökünden gelen 'reis' sözcüğü Osmanlı Türkçesinde hem küçük gemi kaptanı hem de baş/başkan anlamında kullanılmış bir sözcüktür. Osmanlı denizcilik tarihine şöyle bir göz attığımızda büyük Osmanlı donanmasına hizmet vermiş pek çok reise rastlarız. Piri Reis, Oruç Reis, Turgut Reis ve İlyas Reis bunlardan yalnızca birkaçıdır. Ancak sözcüğün kullanımı Osmanlı Türkçesiyle sınırlı değildir. Yüzyıllardır denizcilikle uğraşan Türk halkı bu sözcüğü halen aynı anlamda kullanmaya devam etmektedir. Örneğin balıkçıllğın yaygın olduğu bölgelerden biri olan Karadeniz bölgesinde tekneyi ya da takayı kullanan, deneyimli balıkçı/denizciye kaptan değil 'reis' denir. Sözcügüun ikinci anlamı olan baş/başkan ise onun özellikle bu şiir içinde kullanılmaya uygun olduğunu gösterir. Günümüzde kullanımdan kalkmış ve modern Türkçede 'cumhurbaşkanı' sözcüğü ile yer değiştirmiş olmasına karşın 'reis-i cumhur' sözcüğü aslında hemen her kuşaktan okurun aşina olduğu bir sözcüktür. Can Yücel'in kaynak metindeki 'captain' sözcü̆ünü karşlamak için 'kaptan' yerine, 'reis' sözcüğünü seçmiş olması sözcü̆ün bu çift anlamlılığından kaynaklanmış gibi görünüyor. Kaynak metindeki alegori bu çift anlamlı sözcüğün kullanılmasıyla daha bir belirginleşiyor. Önceki bölümde belirttiğimiz gibi, Walt Whitman'ın şiirinde, kıyıya yaklaşmakta olan geminin kaptanının ani ölümü aslında Amerikan Başkanı Lincoln’n ölümünü simgelemektedir. İngilizcede ‘captain' sözcüğ̈̈nün köküne baktığımızda bu sözcüğün Latince 'baş' anlamı taşıyan 'caput' sözcügünnden türediğini görürüz; yani kaynak metinde 'captain' sözcüğü çift anlamlılı̆̆ıla 'kaptanın ölümü'/'devlet başkanının ölümü' alegorisinin temel yapıtaşıdır. Türkçe çeviride karşımıza çıkan 'reis' sözcüğü de benzer biçimde bu alegorinin kavranmasını kolaylaştırır, şiirdeki çifte anlam katmanına işaret eder.

Başlıkta 'koca' sıfatının kullanılması da ayrıca dikkat çekicidir. Kaynak metindeki 'my' (benim) sözcüğü yerine bu sıfatın kullanılması ilkin yadırgatıcı gelse de kaynak metnin özellikleri dikkate alındığında çeviride bu sıfatın seçilmiş olması anlam kazanır. Kaynak metinde 'my' (benim) sözcüğü geminin kaptanına duyulan sevgi ve hayranlığı vurgular. Erek metinde çevirmen, Türkçede 'yaşlı', 'pir', 'büyük', 'ulu' anlamında kullanılan 'koca' sıfatını seçerek anlatıcının kaptana duyduğu sevgi ve hayranlığı vurgulamak istiyor olabilir. Ayrıca tarihsel çağrışımları açısından zengin olan bu sözcük Türk tarihinde koca sıfatıyla onurlandırılmış önemli isimlere, örneğin Koca Yusuf, Koca Mustafa Paşa, Koca İlyas ve Koca Mehmet Hüsrev Paşa gibi isimlere gönderme yapması açısından da önemlidir.

Yukarıda da belirtildiği gibi çevirinin hemen her dizesinde halk söyleyişlerine ve Türk kültürünü ve tarihini çağrıştıran deyiş ve sözcüklere yer verilmiştir. Örneğin, erek metindeki 'neyleyim' ve 'nideyim' soru sözcükleri çaresizlik ve acı ifade eden, halk türkülerinde bu türden duyguları anlatmak için sıkça kullanılan Anadolu Türkçesine özgü sözcüklerdir. İlk kıtada karşımıza çıkan 'gayri' sözcüğü de gene halk 
dilinde 'artık', 'bundan böyle' anlamına gelen fakat aynı zamanda bezginliği ve çaresizliği vurgulayan ve Türk halk edebiyatında sıkça kullanılan bir sözcüktür. Şiirde 'ağa' sözcüğünün kullanılmış olması da benzer bir duruma işaret eder. Çevirmen, kaynak kültürde birinci dereceden akrabalığı ifade eden ancak kaynak metinde daha çok saygı ifadesi biçiminde karşımıza çıkan 'father' (baba) sözcüğünün karşılı̆̆ı olarak 'ağa' sözcüğünü kullanmayı uygun görmüştür. Çevirmenin buradaki amacı okuru farklı anlamlara göndermek olabilir çünkü Anadolu Türkçesinde 'ağa' sözcüğü 'birinci dereceden yakın akraba, erkek kardeş' anlamına geldiği gibi, halk arasında sayılan ve sözü geçen erkeklere verilen bir unvandır aynı zamanda. Bunlar dışında, erek metinde kullanılan 'bayram etmek', 'davulların çalması', 'alnının akıyla seferden dönmek', 'soğumuş elleri öpmek' ve 'murada ermek' gibi ifadelerin de erek kültürde önemli yer tutan geleneklere gönderme yaptığı açıktır. Bazıları coşku, sevinç ve saygı, bazıları ise derin bir üzüntü anlamı taşıyan bu sözcük ve ifadelerin şiirin trajik atmosferine katkıda bulunduğu da iddia edilebilir.

Erek metnin genelinde erek kültüre ait sözcük, ifade ve sesleniş biçimleri ağırlıklı olsa da Can Yücel'in bazı sözcük seçimleri bu eğilimle bağdaşmaz. Örneğin, anlatıcı 3. ve 9. dizelerde güvertede cansız yatmakta olan gemi kaptanına 'çanların çaldığını' müjdeler. Hıristiyanlık dinini ve kiliseyi akla getiren 'bells' sözcüğü çevirmen tarafından erek metnin bu iki dizesinde korunmuştur. Öte yandan, 21. dizedeki 'ring O bells!' nidası erek metne 'çalsın çanlar' değil de, 'çalsın davullar' biçiminde aktarılmıştır. Yücel’in kaynak metindeki öğeleri hemen her firsatta yerlileştirmeye çalıştığı düşünülürse, 'çan' sözcüğünün erek metinde neden korunduğu merak uyandırır. Çevirmenin bu kararına ilişkin kuşkusuz pek çok farklı yorum yapılabilir. Ancak, Hıristiyanlığın ve kilisenin esasen erek okurun çok da yabancı olmadığı kavramlar olduğu, Anadolu topraklarında Müslümanlık ile birlikte Hıristiyanlığın ve başka birçok dini inanışın yüzyıllar boyu aynı anda varlığını sürdürdüğü değerlendirilirse, Yücel’in bu kararı onun şiirde çok dinli, çok kültürlü, demokratik bir atmosfer yaratmak istemiş olabileceğini akla getirir. Can Yücel’in Walt Whitman’ı “demokrasinin büyük ozanı” diye andığını hatırlarsak, çevirmenin bu stratejisi belki biraz daha anlam kazanacaktır.

Erek metnin biçimsel ve biçemsel özellikleri de çevirmenin amacını ve çeviri metnin erek kültürde nasıl bir işlev üstlendiğini belirlemede bize yardımcı olacaktır. Biçimsel ve biçemsel özellikleri açısından kaynak metne hayli yaklaşan erek metin tıpkı kaynak metin gibi sekizer dizeden oluşan üç kıta biçiminde sunulmuş, kıtaların düzeni kaynak metindekine benzer biçimde oluşturulmuştur. Erek metinde belirgin bir hece ölçüsü düzenine rastlanmıyorsa da kafiye düzeninden söz etmek mümkündür. Zaman zaman tam, zaman zaman da yarım kafiyelerden faydalanan çevirmen a-a, b-b, c-d, e-d / b-b, f-f, d-b, c-d / g$\mathrm{g}, \mathrm{h}-\mathrm{h}, \mathrm{h}-\mathrm{d}, \mathrm{f}-\mathrm{d}$ biçiminde ilerleyen bir kafiye düzeni kullanmıştır. Bu anlamda erek metnin kaynak metinle belli ölçüde benzerlik gösterdiği açıktır.

Biçemle ilgili olarak üzerinde durulması gereken bir başka mesele de Can Yücel’in kullandığı tekrarlardır. En az kaynak metindeki kadar tekrar içerdiği iddia edilebilecek erek metin bu özelliğiyle türkü ve ağıt geleneğine yaklaşır. Erek metinde, sözcük tekrarlarının yanında ses tekrarlarının da önemli yer tuttuğunu fark etmemek olanaksızdır. 4. dizedeki ‘Gördüler pupa yelken geliyor, gözü pek, gözü yeşil yelkenli' ve 19. dizedeki 'Sağ salim demir attı gemi, bitti artık sona erdi sefer' ifadelerinde bu ses tekrarları yoğun biçimde hissedilir. Batı şiirinde olduğu kadar Türk halk ve divan şiirinde de sıkça kullanılan ses tekrarlarından faydalanan çevirmenin bu stratejisi onun erek metnin erek kültürde bir şiir olarak işlev görmesini amaçlamış olabileceğini düşündürür. Ancak, dördüncü dizedeki 'gözü pek, gözü yeşil yelkenli' ifadesinde çevirmenin yelkenliyi 'gözü yeşil' diye nitelemesi özellikle ilgi çekicidir. Erek metne kendi bütünlüğü içinde bakıldığında, yelkenlinin 'yeşil gözlü' olarak tarif edilmesi başlangıçta alışılmışın dışında bir durum gibi görünse de, ifadenin şiir diline has yadırgatıcı bir söyleyiş olarak algılanması pekâlâ mümkündür. Öte yandan, kaynak metinde yelkenlinin yeşil ya da 'yeşil gözlü' 
olduğunu düşündürecek hiçbir ifade bulunmaması, çevirmenin o dizede sözcük ve ses tekrarını da sağlayacak şiirsel bir ifade seçmek istemiş olabileceğini düşündürür. Ancak, yelkenlinin 'yeşil gözlü’ olarak tarif edilmesi, kaynak metindeki alegorik özellikler dikkate alındığında, çevirmenin kararına ilişkin başka bir varsayımı da olanaklı kılar. Kaynak metinde Amerikan ulusunun kurucu babası Abraham Lincoln'ın mücadelesini simgeleyen yelkenlinin erek okura Türk ulusunun bağımsızlık mücadelesiyle özdeşleştirilen 'renkli gözlü’ lideri, Mustafa Kemal’i anımsatacak biçimde sunulmuş olması da muhtemeldir.

Erek metinde kıta sonlarında kullanılan soru ifadeleri de şiirin önemli bir biçemsel öğesi olarak karşımıza çıkar. Çevirmenin ilk kıtayı bitirirken 'Soğumuş ellerini mi öpeyim?', sonraki kıtaların son dizesi olarak da 'Bu kan damlalarını nideyim?' ve 'Böyle dolaşmayı da nideyim?' soru ifadelerini kullanmış olması onun ağıt geleneğine yaklaşmayı amaçladığını düşündürür, zira soru ifadelerinin kullanımı ağıtların en önemli özelliklerinden biridir. Ağıtlarda kullanılan soru ifadeleri ölenin ya da geride kalanın içinde bulunduğu trajik durumun altını çizmek gibi önemli bir işlev üstlenirken bu soruların şiir boyunca yinelenmesi ise okurun zihninde kalıcı bir etki yaratılmasına katkıda bulunur (Tavukçu, 2009). Kaynak metinde soru biçiminde ifade edilmeyen ve 'fallen cold and dead' biçiminde her üç kıtanın sonunda tekrarlanan son dizeler kısalıklarıyla şiirin ritmini yavaşlatıp ağıt atmosferinin yaratılmasına katkıda bulunur. Erek metinde bunlar, her kıtanın sonunda farklı sorular biçiminde karşımıza çıkıyor olsa da erek metinde her kıtanın ilk dört dizesinde kendini gösteren coşkulu söylemin kıta sonlarında yerini nihai bir çaresizlik duygusuna bırakmasını sağlamaları açısından da önemlidir.

\section{Sonuç}

Kaynak ve erek metinlere kendi kültür ve edebiyat dizgelerinde üstlendikleri işlevler açısından bakıldığında iki metin arasındaki benzerlikler dikkat çekicidir. Kaynak metin Batı edebiyatında deniz temasını işlemiş nice seçkin örnekten ve özellikle de deniz yolculuğu temasını politik alegori olarak kullanma geleneğinden izler taşır. Ayrıca, hem içeriğiyle, hem de geleneksel biçim ve biçemiyle bir lirik şiir türü olan ağıt türüne yaklaşır. Erek metnin de, Türk halk edebiyatındaki ağıt türünü çağrıştıracak biçimde kurgulanmış olduğunu söylemek yanlış olmayacaktır. Çevirmenin erek metni halk deyişleriyle ve erek okuru kendi geleneklerine ve tarihine gönderen sözcük ve sözcük öbekleriyle zenginleştirmiş olması da, aslında, metindeki ağıt atmosferini yoğunlaştırmak istemesine bağlanabilir. Ayrıca, çevirinin kilit noktalarında çok anlamlı sözcüklerin kullanılmış olması kaynak metindeki alegorik özelliklerin çevirmen tarafından çok iyi kavrandığına ve erek metinde korunmak istendiğine işaret etmektedir. Kaynak metinde durum karşıtlığı biçiminde ifade bulan tragedya özellikleri de çeviri metinde fazlasıyla hissedilmektedir. Dolayısıyla, erek ve kaynak metinler arasındaki dilsel farklılıklar, bir anlamda, kaynak metindeki ağıt özelliğinin ve trajik atmosferin korunmasına hizmet etmektedir. Öyleyse yukarıda yapılan çeviri eleştirisi sonucunda, erek ve kaynak dil, kültür ve edebiyat dizgelerinin farklılığına bağlı olarak, erek ve kaynak metinlerde dilsel öğeler birbirinden ciddi ölçüde farklılaşıyor olmasına karşın bu iki metin arasında işlevsel açıdan bir 'tutarlılık' bulunduğunu söylemek mümkündür. Tam da diller ve kültürler arasındaki farklılıklardan ötürü gerekli, hatta kaçınılmaz olan çeviri etkinliği sayesinde özgün metin bir başka dilin ve kültürün sınırları içinde bir şiir, hatta alegorik özellikler taşıyan bir ağıt olarak varlığını sürdürür, yeni anlamlar üretir, özgün metnin anlam katmanlarına yenilerini ekleyerek onu bir anlamda çoğaltır. Bu bakımdan, erek metnin, Can Yücel’in özgün yapıt ve çeviri yapıt arasında statü açısından bir fark bulunmadığı ve şiir çevirisinde çevirinin bir şiir olarak işlev görmesi gerektiği yolundaki genel yaklaşımıyla da uyum içinde olduğu söylenebilir. 
Hans J. Vermeer ve Margaret Ammann tarafından ortaya atılan çeviri eleştirisi yönteminin, çeviri yoluyla üretilen yeni anlamların izini sürmede eleştirmene yol gösterdiği, onu çevrilebilirlik/çevrilemezlik ikiliğinin tuzağına düşmekten kurtardığı açıktır. Hiç kuşkusuz, bu yöntem çerçevesinde yürütülen bir çeviri eleştirisi çalışmasında eleştirmenin yapabileceği değerlendirmeler ve varacağı sonuçlar, geleneksel dilbilimsel anlayışla, yani dilsel ikili karşıtlıkların birbiriyle karşılaştırılması üzerinden yapılacak bir incelemede varılabilecek sonuçlardan çok faklı olacaktır. Geleneksel dilbilimsel anlayışla yürütülen bir eleştiri çalışmasında, örneğin, 'çanlar' sözcügünü 'davullar' sözcügüyle karşlamayı seçen Can Yücel'in kaynak metindeki anlamı çarpıttığı, bozduğu, hatta yok ettiği ya da erek metnin çeviri sayılamayacağı, ancak bir uyarlama biçiminde ele alınması gerektiği yolunda sonuçlara varılması işten bile değildir. Ülkemizde bugün bile bu türden eleştirel çalışmaların ve değerlendirmelerin karşımıza çıkıyor olması, kültür kuramcılarının çeviribilime yaptıkları katkıların ve yapısalcılık sonrası düşüncenin Türkiye'de çeviri eleştirisi alanında çalışan araştırmacılardan bazıları tarafından görmezden gelindiğini düşündürmektedir. Dolayısıyla, erek ve kaynak metinler arasındaki kaçınılmaz dilsel farklılıkları 'bozulma', 'anlam yitimi', 'eksiklik', 'kayıp' gibi kavramlarla açılamaya çalışanlara, bu yaklaşımlarının temelinde çevrilemezlik düşüncesinin, yani metinlerin biçimsel, biçemsel ya da anlamsal açıdan hiçbir değişikliğe uğramadan kalması gerektiği ve anlamın sabit olduğu yolundaki özcü anlayışın yattığını, erek metnin asla kaynak metnin aynısı olamayacağını, zaten çevirinin de diller ve kültürler arasındaki farklardan ötürü gerekli olduğunu, dilin ancak ayrımlar üzerinden anlam ürettiğini ve çevirinin yeni anlamların üretilmesine hizmet eden bir etkinlik olarak algılanması gerektiğini ne kadar hatırlatsak azdır. Eyüboğlu'nun tam 61 yl önce büyük bir öngörüyle kaleme aldığı giriş yazısında "ha sen söylemişsin ha ben", şairin şairle kaynaşması", "bir dille iki dilin tadını almak, bir canla iki canın sevincini duymak" diye tarif ettiği şey işte çevirinin bu yeni anlamlar üretme özelliğidir.

\section{Kaynakça}

Akcan, E. (2009). Çeviride Modern Olan. İstanbul: Yapı Kredi Yayınları.

Alova, E. (2007). “Bir İstandollu’nun Notları”. Sözcükler. Mart-Nisan, İstanbul, s. 44-57.

Altay, A. (2001). “Şiir Çevirisinde Çevrilemeyenler”. Hacettepe Üniversitesi Edebiyat Fakültesi Dergisi. Ankara, cilt 18, sayı 1: 29-43.

Ammann, M. (1990). "Anmerkungen zu einer Theorie der Übersetzungskritik und ihrer praktischen Anwendung”. Heidelberg: TEXTconTEXT. No. 5: 209-250.

Arrojo, R. (1995). "The 'Death' of the Author and the Limits of the Translator's Visibility". In M. SnellHornby, Z. Jettmarová \& K. Kaindl (Eds.), Translation as Intercultural Communication (pp. 2132). Amsterdam, Philadelphia: John Benjamins Publishing Company.

Arrojo, R. (1996). "Literature as Fetishism: some Consequences for a Theory of Translation". Meta. Volume 41, Numéro 2, Juin: 208-216.

Arrojo, R. (1998). "The Revision of the Traditional Gap Between Theory and Practice and the Empowerment of Translation in Postmodern Times". The Translator. Volume 4, no 1: 25-48.

Bengi-Öner, I. (1993). "Çeviri Eleştirisi Bağlamında Eleştirel Bilincin Oluşması ve Eleştiri, Üsteleştiri, Çeviribilim İlişkileri”. Dilbilim Araştırmaları. Ankara: Hitit Yayınları, s. 25-50.

Berk, İ. (1978). “Çeviride Şiir Dili”. Türk Dili: Çeviri Sorunları Özel Sayısı. Ankara, Sayı 322.

Berk, Ö. (2005). Kuramlar Işığında Açıklamah Çeviribilim Terimcesi. İstanbul: Multilingual Yayınları. Catford, J. C. (1965). A Linguistic Theory of Translation. Oxford: OUP.

Culler, J. (1997). Literary Theory: A Very Short Introduction. New York: Oxford University Press.

Davis, K. (2001). Deconstruction and Translation. Manchester: St. Jerome Publishing. 
Erten, A. (1993). “Çeviri Ediminde Kayılar Sorunu”, Hacettepe Üniversitesi Edebiyat Fakültesi Dergisi. Cilt 10, sayı 1: 315-330.

Even-Zohar, I. (1985). "Yazınsal ‘Polisistem’ İçinde Çeviri Yazının Durumu”. çev. Saliha Paker. Adam Sanat. S. 14. İstanbul: Adam Yayınları, s. 59-68.

Eyüboğlu, S. (1993). “Can Yücel’in Şiir Çevirileri”. Her Boydan: Dünya Şiirinden Örnekler. İstanbul: Papirüs Yayınları (4. baskı).

Ferber, M. (1999). Dictionary of Literary Symbols. West Nyack, NY, USA: Cambridge University Press.

Fillmore, C. (1977). "Scenes-and-Frames Semantics”. A. Zambolli (ed). Linguistic Structure Processing (pp. 55-82). Amsterdam: North Holland Publishing Company.

Gidmark, J. B. (ed.). (2000). Encyclopedia of American Literature of the Sea \& Great Lakes. Westport, CT, USA: Greenwood Publishing Group, Incorporated.

Göktürk, A. (2008). Çeviri: Dillerin Dili. İstanbul: Yapı Kredi Yayınları.

Güttinger, F. (1963). Zielscprache. Theorie und Technik des Übersetzens. Zürich: Manesse Verlag.

Hermans, T. (2009). “Translatability”. In Baker, M and Saldanha, G, (eds.), Routledge Encyclopedia of Translation Studies (pp. 300-303). Routledge: London and New York.

Isham, H. F. (2004). Image of the Sea: Oceanic Consciousness in the Romantic Century. New York, USA: Peter Lang Publishing, Incorporated.

Kade, O. (1968). Zufall und Gesetzmaessigkeit in der Übersetzung. München: Wilhelm Fink Verlag.

Karantay, S. (1989). "Can Yücel ile Söyleşi”. Metis Çeviri Araştırmaları Dergisi. İstanbul, Yaz, sayı 8, s. 11-18.

Koller, W. (1979). Einführung in die Übersetzungswissenschaft. Heidelberg: Quelle und Mayer.

Kuçuradi, İ. (1978). “Şiir Çevirisini Değerlendirme ve Türkçe'de Homeros”. Türk Dili: Çeviri Sorunları Özel Sayısı. Ankara, Sayı 322.

LeMaster J. R. and D. D. Kummings (eds). (1998). The Routledge Encyclopedia of Walt Whitman. New York: Routledge.

Nida, E. (1964). Towards a Science of Translating with Special Reference to Principles and Procedures Involved in Bible Translating. Lieden.

Popovič, A. (1970). “The Concept of 'Shift of Expression' in Translation”. ed. J. Holmes, F. de Haan, A. Popovič. The Nature of Translation: Essays on the Theory and Practice of Literary Translation. The Hague: Mouton de Gruyter, pp. 78-87.

Reynolds, D. S. (2005). Walt Whitman. Cary, NC, USA: Oxford University Press, Incorporated.

Schäffner, C. (1998/2001). "Skopos Theory". Baker M. (ed.). Routledge Encyclopedia of Translation Studies (pp. 236-238). London: Routledge,.

Tavukçu, O.K. (2009). “Türk Edebiyatında Ölüm Şiirlerinin Bazı Üslûp Özellikleri”, Motif Akademi, 12: s. 59-73.

Tellioğlu, B. (1998). Reflections of Gideon Toury's target-Oriented Theory and Hans J. Vermeer's Skopos Theory on Translation Criticism: A Meta-critique. Yayımlanmamış yüksek lisans tezi. Boğaziçi Üniversitesi Sosyal Bilimler Enstitüsü. İstanbul.

Tellioğlu, B. (2015). Çeviride Makul, Makbul ve Müphem: Çeviri Etiği, Meslek İlkeleri ve Bireysel Ahlak. Yayımlanmamıș doktora tezi. Yıldız Teknik Üniversitesi Sosyal Bilimler Enstitüsü. İstanbul.

Toury, G. (1985). "A Rationale for Descriptive Translation Studies". Theo Hermans (ed.). The Manipulation of Literature: Studies in Literary Translation (pp. 16-41). Beckenham: Croom Helm.

Toury, G. (2004). “Çeviri Normlarının Doğası ve Çevirideki Rolü”. Mehmet Rifat (der.). Çeviri Seçkisi: Çeviri(bilim) Nedir? (s. 149-164). İstanbul: Dünya Yayınevi. 
Vermeer, Hans J. (1990). Mögen Sie Zistrosen?. Heidelberg: TEXTconTEXT.

Vermeer, Hans J. (1996). A Skopos Theory of Translation (Some Arguments for and against). Heidelberg: TEXTconTEXT (Wissenschaft).

Vermeer, Hans J. (1998/2001). “Didactics of Translation”. M. Baker (ed.). Routledge Encyclopedia of Translation Studies (pp. 60-63). London: Routledge.

Vermeer, Hans J. (2002). "Apparent contradictions in 16th century reports on Turkey". (ed.) Hasan Anamur. Aspects culturels de la traduction: En hommage à Hasan-Ali Yücel (pp. 85-96). Istanbul 23-25 Ekim 1997. Actes du Ir Colloque International de Traduction. Istanbul 2002.

Vermeer, Hans J. (2004). “Çevirinin Doğası-Bir Özet”. Çeviri Seçkisi: Çeviri(bilim) Nedir?. (der.) Mehmet Rifat. (çev.) Dilek Dizdar. İstanbul: Dünya Yayınevi.

Whitman, W. (1996). Selected Poems. London: Penguin Books.

Yücel, C. (1993). Her Boydan: Dünya Şürinden Örnekler. İstanbul: Papirüs Yayınları, (4. baskı). 